\author{
RADOSEAW KOTECKI \\ Uniwersytet Kazimierza Wielkiego \\ w Bydgoszczy
}

\title{
AETERNUM DEI SERVITIUM AD SANCTUM LOCUM. POKUTA ZABÓJCÓW PIĘCIU BRACI MĘCZENNIKÓW W RELACJI BRUNONA Z KWERFURTU
}

W polskiej historiografii istnieje pewna tradycja badań nad praktykami pokutnymi we wczesnym średniowieczu ${ }^{1}$. Tradycja ta przedstawia się jednak skromnie, co oczywiście z wielu względów nie dziwi. Główną przyczyną tego stanu rzeczy są dotkliwe niedostatki bazy źródłowej - problem, na który badacze zwracali uwagę. A mimo to do tej pory nie dostrzeżono wagi dwóch jedenastowiecznych przekazów źródłowych.

Tymi źródłami są dwa najstarsze teksty hagiograficzne wspominające o posłudze, zamordowaniu i kulcie tzw. Pięciu Braci Męczenników, czyli eremitów z kręgu św. Romualda ${ }^{2}$ osiadłych w 1001 r. w domenie piastowskiej, w nieznanej bliżej lokalizacji na terytorium podległym jurysdykcji biskupa Ungera ${ }^{3}$. Starszy z nich to przekaz spisany przez św. Brunona

${ }^{1}$ B. Ulanowski, 0 pokucie publicznej $w$ Polsce, RWHF PAU 23, 1888, s. 61-172; S. Bieniek, Z dziejów pokuty publicznej w Polsce wczesnofeudalnej, CPH 18, 1966, 2, s. 9-28; B. Wojciechowska, Kary kościelne w Polsce wczesnośredniowiecznej (X-XIII w.), CPH 57, 2005, 2, s. 267-282; eadem, Ekskomunika w Polsce średniowiecznej. Normy i funkcjonowanie, Kielce 2010, s. 133-141, a także z innej perspektywy Z. Dalewski, Rytuał i polityka. Opowieść Galla Anonima o konflikcie Bolesława Krzywoustego ze Zbigniewem, Warszawa 2005, s. 102-159; idem, Boleslaw Wrymouth's Penance and Gallus Anonymous' Chronicle, w: Gallus Anonymous and His Chronicle in the Context of Twelfth-Century Historiography, red. K. Stopka, Kraków 2010, s. 125-140.

${ }^{2}$ Chodzi o przybyłych z Pereum Benedykta oraz Jana. Do nich w Wielkopolsce dołączyli Słowianie - bracia Mateusz i Izaak, a także sługa Krystyn. Literaturę przedmiotu cytują: A. Pleszczyński, Bolesław Chrobry konfratrem eremitów w Międzyrzeczu, KH 103, 1996, 1, s. 4, przyp. 7; P. Stróżyk, Śmierć eremitów w relacji Brunona z Kwerfurtu, RH 69,2003 , s. 8 , przyp. 2.

${ }^{3}$ Niedawno, po opublikowaniu nowych wniosków Tomasza Jurka, upadła obowiązująca niemal powszechnie hipoteza, według której lokalizację eremu Pięciu Braci 
z Kwerfurtu znany jako Vita Quinque Fratrum Eremitarum (1006 lub 1008/ 1009), poświęcony w całości upamiętnieniu dzieła męczenników. Jest to żywot w pewnej mierze wyjątkowy na tle hagiografii wczesnośredniowiecznej, gdyż relacjonujący zdarzenia z krótkiej perspektywy czasowej oraz znane autorowi z autopsji lub z pierwszej ręki ${ }^{4}$. Drugim z przekazów jest natomiast Żywot św. Romualda autorstwa Piotra Damianiego tekst znacznie późniejszy (ok. 1042), a w wątkach polskich oparty głównie (lub nawet wyłącznie) na zasłyszanych relacjach najstarszych uczniów ojca eremityzmu kamedulskiego ${ }^{5}$.

Okazuje się, iż oba źródła posiadają znaczną wartość dla badania znajomości zwyczajów pokutnych w państwie Bolesława Chrobrego. Ich potencjał wynika z faktu, iż zarówno Bruno z Kwerfurtu, jak i Piotr Damiani uznali za istotne nie tylko dać świadectwo męczeństwu eremitów, ale także wspomnieć o losie, jaki spotkał sprawców okrutnej zbrodni doko-

upatrywano w nadobrzańskim Międzyrzeczu. Badacz przekonująco udowodnił, iż w pobliżu tej miejscowości, w osadzie Święty Wojciech, mieścił się klasztor założony przez biskupa praskiego. Zob. T. Jurek, „Ad Mestris locum”: Where Was the Monastery Founded by Saint Adalbert Situated?, APH 2011,103, s. 5-25. Wcześniej trwała dyskusja nad kwestią lokalizacji eremu. Główne stanowiska zajmowane w jej trakcie omówił Miłosz Sosnowski, Co wiadomo o lokalizacji pustelni tzw. Pięciu Braci?, RH 71, 2005, s. 7-29. Wydawać by się mogło, iż w związku z nowymi konkluzjami wzmocnieniu ulegają hipotezy wskazujące na lokalizację eremu w miejscowości o nazwie Kazimierz (pod Szamotułami lub Kazimierz Biskupi), co ma uzasadnienie w informacjach Rocznika poznańskiego starszego i Rocznika kamienieckiego. Jak jednak pokazał Tomasz Jasiński, identyfikacje te mają słabe podstawy, gdyż takiej treści nie da się wywieść z Rocznika kapitulnego krakowskiego, wiadomość zaś o Kazimierzu pochodzi od autora Rocznika poznańskiego starszego z XIII w. Jej wartość jest więc niska, zwłaszcza iż treść wpisu w Roczniku kamienieckim także jest odeń zależna. Zob. T. Jasiński, Zapiski kronikarskie i rocznikarskie o Pięciu Braciach Męczennikach, w: Kult Pięciu Braci Męczenników w Kazimierzu Biskupim, red. R. Jałoszyński, Kazimierz Biskupi 2003, s. 19-29.

${ }^{4}$ Bibliotheca hagiographica latina antiquae et mediae aetatis, t. 1-2, Bruxellis 1898-1901 (dalej: BHL), nr 1147. Najlepszą edycję źródła stanowi Vita Quinque Fratrum Eremitarum [seu] Vita uel Passio Benedicti et Iohannis sociorumque quorum auctore Brunone Querfurtensi, wyd. J. Karwasińska, Warszawa 1973, MPH s.n., t. 4, cz. 3 (dalej: VQF). Cytaty polskie za Brunon z Kwerfurtu, Żywot Pięciu Braci Męczenników, tłum. E. Szwarcenberg-Czerny, Kraków 2002 (dalej: ŻPB). Na temat źródła m.in. B. Kürbis, „Purpureae passionis aureus finis". Brun z Kwerfurtu i Pięciu Braci eremitów, w: eadem, Na progach historii, t. 2, Poznań 2001, s. 163-180; A. Kuźmiuk-Ciekanowska, Piśmiennictwo świętego Brunona z Kwerfurtu, w: Święty Brunon. Patron lokalny czy symbol jedności Europy i powszechności Kościoła, red. A. Kopiczko, Olsztyn 2009, s. 309-314; E. Skibiński, Kompozycja tzw. Żywota Pięciu Braci Męczenników Brunona z Kwerfurtu, w: Bruno z Kwerfurtu. Osoba - dzieło - epoka, red. M. Dygo, W. Fałkowski, Pułtusk 2010, s. 279-286.

${ }^{5}$ BHL, t. 2, Bruxellis 1900-1901, nr 7324. Petri Damiani Vita Beati Romualdi, wyd. G. Tabacco, Roma 1957, Fonti per la storia d'Italia, vol. 94 (dalej: VBR), c. 28, s. 64. W historiografii nie ma zgody co do wiarygodności polskich wątków w dziele Damianiego. Problem ten wymaga nadal pogłębionej analizy. 
nanej w listopadową noc 1003 r. Dzięki temu historyk ma szanse dowiedzenia się, iż zabójcy braci zostali ujęci przez ludzi księcia wkrótce po tym, jak dokonali zbrodni, a nastęnie poddano ich sankcjom, z których część była inspirowana zwyczajami i normami pokutnymi funkcjonującymi w tym czasie na zachodzie Europy.

Chociaż oba źródła przedstawiają znaczną wartość dla badań nad problematyką pokuty, a także istnieje możliwość wzajemnego konfrontowania owych przekazów w celu uzyskania pełniejszych wniosków, niniejsze studium dotyczyć będzie wyłącznie przekazu Kwerfurtczyka. Takie skoncentrowanie się na jednym tylko źródle wydaje się zasadne z kilku względów. Przede wszystkim należy zauważyć, iż Vita Quinque Fratrum jest utworem chronologicznie bardzo bliskim omawianym wypadkom, a jego autor był lepiej poinformowany o przebiegu pokuty morderców niż piszący później Damiani. Bruno miał bowiem okazję naocznie obserwować zabójców już w roli penitentów, co zdecydowanie podnosi wartość jego relacji. Te czynniki sugerują, aby w pierwszej kolejności skoncentrować się właśnie na Żywocie Pięciu Braci, jako na źródle dla podejmowanej tematyki najwartościowszym. Poza tym oba przekazy oświetlają dwa różne etapy ekspiacji morderców, a zarazem realizację odmiennych form pokutnych. Podczas gdy Damiani wspomniał o pewnych aktach ekspiacyjnych, do realizacji których mordercy zostali zmuszeni na wczesnym etapie pokuty, Bruno skoncentrował się na docelowej formie penitencji zabójców, wyrażającej się przez konieczność dożywotniego przebywania w klasztorze ufundowanym na miejscu eremu. To sprawia, iż możliwe jest rozdzielne analizowanie owych przekazów. Konieczność referowania szerokiej palety źródeł dla celów porównawczych, a także potrzeba dodatkowej krytyki przekazu Damianiego każą omówić jego relację w osobnej odsłonie.

Celem niniejszego studium jest więc odczytanie fragmentów Żywota Pięciu Braci pod kątem zawartych w dziele informacji o pokucie zabójców eremitów. Zestawienie uzyskanych wiadomości ze źródłami powstałymi na terenie Europy łacińskiej wczesnego średniowiecza ukazać ma analogie pokuty nałożonej na zabójców obecne w prawodawstwie i zachodnioeuropejskiej praktyce penitencjarnej, a tym samym wskazać na źródła inspiracji, którymi kierował się „autor” sankcji nałożonej na sprawców śmierci eremitów. Ich rozpoznanie rzucić winno nie tylko nieco światła na kwestię pokutowania w domenie wczesnopiastowskiej, ale także na szerszy problem posługiwania się w państwie Chrobrego uregulowaniami ze świata kultury Zachodu. Co za tym idzie, dać może pewien wgląd w rolę samego władcy na tym polu. Niniejsze studium wpisuje się więc w nurt badań nad kwestiami chrystianizacji państwa piastowskiego, rozumianej jako proces 
jego wiązania z kręgiem postkarolińskiej cywilizacji łacińskiej na drodze akulturacji zwyczajów i norm chrześcijańskich ${ }^{6}$.

Co zatem o losie zabójców Pięciu Braci do powiedzenia ma autor Vitae Quinquae Fratrum? Otóż z treści Żywota wynika, iż niedługo po tym, jak ich pochwycono, mordercy zostali wtrąceni do książęcego więzienia. W oparciu o słowa Brunona nie sposób jednak stwierdzić, jak do tego doszło, ani czy sprawcy zbrodni oczekiwać mieli w nim na wykonanie wyroku śmierci, czy też raczej spędzić resztę życia. Zakładać jednak raczej należy, iż nie mieli opuścić zamknięcia żywi, skoro zdaniem Kwerfurtczyka była to „dira custodia", a sam fakt ich uwięzienia skazywać miał dzieci, żony sprawców na kompletną ruinę ${ }^{7}$.

Bez względu na potencjalne rozstrzygnięcia powyżej kwestii istotniejsza jest wiadomość, iż pobyt zabójców w więzieniu okazał się tylko przejściowym etapem kary, po którym nastąpiło ich przeniesienie do klasztoru pobudowanego „super corpora sanctorum”, a więc na miejscu eremu ${ }^{8}$. Z przekazu nie wynika wprost, co dokładnie sprawiło, że władca wykazał się taką łaskawością wobec zbrodniarzy, ofiarowując im możliwość życia w lepszych warunkach niż dotychczasowe. Wiadomość ta może dziwić zwłaszcza w zderzeniu ze świadectwem Thietmara o rodzajach kar stosowanych przez księcia względem złoczyńców godzących w promowany ład chrześcijański ${ }^{9}$. Dziwić może tym bardziej, jeśli uświadomić sobie, jaką wartość przedstawiali eremici w jego planach politycznych i misyjnych, i że władcę z zakonnikami łączyła też więź duchowego braterstwa ${ }^{10}$. Książę miał więc wszelkie argumenty w ręku, aby móc rozprawić się ze sprawca-

${ }^{6}$ Szczególne znaczenie dla problemu recepcji zachodnich zwyczajów w domenie Chrobrego mają badania Romana Michałowskiego nad kwestią długości trwania okresu postnego: idem, The Nine-week Lent in Boleslaus the Brave's Poland. A Study of the First Piasts' Religious Policy, APH 2004, 89, s. 5-50. Nie mniej istotne są szersze ujęcia tego autora: idem, Christianisation of Political Culture in Poland in the $10^{\text {th }}$ and Early $11^{\text {th }}$ Century, w: Political Culture in Central Europe, t. 1, red. H. Manikowska, J. Pánek, Prague 2005, s. 31-46; idem, Christianisation of the Piast Monarchy in the $10^{\text {th }}$ and $11^{\text {th }}$ Centuries, APH 2010,101 , s. 5-35. Ze starszych opracowań zob. A. Gieysztor, Przemiany ideologiczne w państwie pierwszych Piastów a wprowadzenie chrześcijaństwa, w: Początki państwa polskiego, t. 2, red. K. Tymieniecki, Poznań 1962, s. 155-170; A. Vetulani, Przemiany w urządzeniach i życiu prawnym społeczeństwa w poczatkach państwa polskiego, w: Poczatki państwa polskiego, s. 171-188; W. Sawicki, Studia nad wpływem praw obcych w dawnej Polsce, Warszawa 1971. Z nowszych natomiast L. Wetesko, Piastowie i ich państwo w łacińskiej Europie. Studia z dziejów kultury politycznej X i XI wieku, Poznań 2013.

${ }^{7}$ VQF, c. 25, s. 76.

${ }^{8}$ Por. P. Stróżyk, op. cit., s. 21; L. Wetesko, Historyczne konteksty monarszych fundacji artystycznych w Wielkopolsce do początku XIII wieku, Poznań 2009, s. 114-128.

${ }^{9}$ Die Chronik des Bischofs Thietmar von Merseburg, wyd. R. Holtzmann, Berlin 1935, MGH SrG n.s., t. 9, lib. VIII, c. 2, s. 494.

${ }^{10}$ A. Pleszczyński, op. cit. 
mi mordu, a zarazem podwójnego świętokradztwa z pełną surowością. A jednak Bolesław Chrobry tego nie uczynił, co więcej, zgodził się, by zabójcy mogli żyć w obrębie przestrzeni świętej odgrodzonej klauzurą od świata i świeckich ${ }^{11}$.Paść więc w tym miejscu powinno pytanie: co spowodowało taki obrót sprawy? Niestety Brunon nie udzielił na nie w pełni wiarygodnej odpowiedzi.Jego zdaniem to święci męczennicy uratowali morderców przed długoletnim uwięzieniem lub śmiercią, a przy tym ich rodziny i dobytek przed ruiną, stanowczo ingerując na ich korzyść w ziemski tok spraw.Ukazując się we śnie jednemu z zakonników służących w nowo fundowanym opactwie, konkretnie bratu Andrzejowi, wymogli na nim, by nawet wbrew woli opata przekazał on księciu żądanie przeniesienia zabójców do klasztoru ${ }^{12}$. W ten sposób, chcąc ukazać wręcz Chrystusowe miłosierdzie męczenników, Bruno na zawsze zataił część czynników, które doprowadziły do podjęcia decyzji o umieszczeniu morderców przy konwencie.

Pomimo pewnych niejasności przekazanie morderców na rzecz opactwa w świetle narracji Brunona nie budzi najmniejszych wątpliwości. Kwerfurtczyk, przebywając w opactwie w 1006 r. lub też na przełomie lat $1008 / 1009^{13}$, miał nie tylko okazję ujrzeć zbrodniarzy, ale również nawiązać z nimi kontakt. Jak sam przyznał, czerpał od nich - zwłaszcza od prowodyra zbrodni - informacje o przebiegu mordu, które następnie wykorzystał przy tworzeniu opisu męczeństwa ${ }^{14}$.

By lepiej zrozumieć charakter pobytu morderców w klasztorze oraz ich docelowej roli w ramach konwentu, a zarazem pojąć sens decyzji umieszczenia ich tam, należy przyjrzeć się bliżej informacjom podanym przez Kwerfurtczyka. Pomimo iż jego świadectwa wydają się lakoniczne, to są jednak na tyle konkretne, żeby wyłącznie na podstawie treści Żywota móc postawić tezę, iż sprawcy zbrodni przekazani zostali do klasztoru, aby tam pokutować. W pierwszej kolejności należy zauważyć, iż Bruno, odnosząc się do charakteru pobytu morderców w klasztorze, aż czterokrotnie posłużył się formami słowa poeniteo: 1) „carnifex, qui percussit eos postea penitens”; 2) "carnifex penitendo hec narrans”; 3) „percussor [- - ] valde penitet”; 4) „[mordercy] more suo post tempus tedere et penitere ceperunt” ${ }^{15}$.Choć tłumacze Żywota na język polski - zarówno Kazimierz Abgarowicz, jak i Ewa Szwarcenberg-Czerny - dopuszczalnie oddali wszystkie te terminy,

${ }^{11}$ W kwestii izolowania klasztorów od świeckich w XI w. zob. M. de Jong, Internal Cloisters: The Case of Ekkehard's „Casus Sancti Galli”, w: Grenze und Differenz im frühen Mittelalter, red. W. Pohl, H. Reimitz, Wien 2000, s. 209-221, gdzie dalsza literatura.

${ }^{12} \mathrm{VQF}, \mathrm{c} .25$, s. 75-76.

13 O datacji pobytów Brunona w klasztorze J. Karwasińska, Wstęp, w: VQF, s. 15-16.

${ }^{14}$ Fakt ten potwierdził Bruno aż trzykrotnie. Zob. VQF, c. 13, s. 62, 65.

${ }^{15}$ Ibidem. 
jako mające w zamyśle autora wyrażać żal i skruchę oprawców ${ }^{16}$, to nie ma powodu, by odczytywać je tu z pominięciem konotacji penitencjarnych, jakie wyrażenie to posiadało ${ }^{17}$. Niezależnie jednak od tych wątpliwości ostatecznie o statusie pokutnym morderców przekazanych do klasztoru przekonuje inny fragment Vitae, mianowicie treść żądania, jakie święci wyjawili bratu Andrzejowi. Otóż męczennicy wymóc mieli na zakonniku, aby ten udał się do księcia Bolesława z postulatem umieszczenia sprawców mordu w opactwie, co - jak zapisał Bruno - dałoby im sposobność odbycia pokuty ${ }^{18}$.W tym przypadku nie może być wątpliwości, iż Kwerfurtczyk użył terminu paenitentia na określenie pokutowania. Co za tym idzie, należy założyć, iż zbrodniarze celowo zostali umieszczeni w opactwie, by mogli tam dostąpić dobrodziejstwa pokuty. Choć wniosek wypływający z przeprowadzonej analizy wydaje się oczywisty, dotychczas niemalże nie brano takiego rozwiązania pod uwagę. Dopiero Paweł Stróżyk skonstatował niedawno, iż zabójców „skazano na pokutę w klasztorze”. Wniosek ten, choć trafny, postawiony został jednak bez przekonywającego uzasadnienia. Nie może być więc uznany za wystarczający, tym bardziej że badacz powiązał go z błędnym domniemaniem, iż główny wykonawca zbrodni został zesłany do klasztoru, gdyż był to najstarszy syn Chrobrego - książę Bezprym ${ }^{19}$.

${ }^{16}$ Brunon z Kwerfurtu, Żywot Pięciu Braci Męczenników, tłum. K. Abgarowicz, w: Piśmiennictwo czasów Bolesława Chrobrego, wstęp, koment. i oprac. J. Karwasińska, Warszawa 1966, s. 214, 216; ŻPB, s. 81, 85.

${ }^{17}$ Mediae latinitatis lexicon minus, vol. 2, red. J. F. Niermeyer et al., Leiden 2002, s. 783, sv. paenitere.

18 „ut possint habere penitentiam”, VQF, c. 25, s. 76.

${ }^{19}$ P. Stróżyk, op. cit., s. 29. Badacz przywołał kilka pośrednich argumentów mających świadczyć o tym, że przywódcą zabójców był książę Bezprym (s. 24-29). Naczelnym tego dowodem ma być informacja z VBR, według której pewien syn Chrobrego wstąpił do klasztoru za zgodą św. Romualda. Zdaniem P. Stróżyka nie chodziło jednak o erem w Pereum, lecz klasztor utworzony na miejscu pustelni Pięciu Braci. Badacz odrzucił tym samym utrwaloną w polskiej historiografii tezę, zakładającą, iż wstąpienie do klasztoru w Pereum było jednoczesne z ofiarowaniem św. Romualdowi konia przez tegoż Piastowicza, o czym Damiani wspomniał w jednym zdaniu. Owo zdanie: „Habebat [scil. Romualdus - R.K.] autem equum satis egregium, quem sibi Busclavi Sclavonici regis filius dederat, factus ab eo monachus" (VBR, c. 28, s. 64-65), wskazuje jednak na bliski związek owych faktów, gdyż od nowicjuszy wymagano, by wstępując do zgromadzenia, ofiarowywali na jego rzecz pewne dobra. Należy poza tym zakładać raczej, iż jeśli przekaz mówi o Bezprymie, to jego pobyt klasztorze nie miał charakteru pokuty, lecz spowodowany został dążeniem Chrobrego do zamknięcia przed synem drogi do władzy. Na taką możliwość interpretacji wskazał ostatnio Zbigniew Dalewski, Koronacja Mieszka II, w: Historia narrat. Studia mediewistyczne ofiarowane Profesorowi Jackowi Baszkiewiczowi, red. A. Pleszczyński et al., Lublin 2012, s.118. Uzasadnienie P. Stróżyka upada jednak, jeśli zapytać, dlaczego mnichem w polskim opactwie miałby go uczynić właśnie św. Romuald. Klasztor wzniesiony przy grobach Pięciu Braci miał przecież swego opata i to od jego decyzji zależało (w praktyce być może od Bolesława Chrobrego), dla kogo 
Koniecznie należy zauważyć, iż fragment relacjonujący rzekome żądania wyjawione przez męczenników bratu Andrzejowi zawiera jeszcze jeden istotny element. Okazuje się on kluczowy dla zrozumienia sankcji, jaką ostatecznie nałożono na zabójców eremitów. Jako że znaczenie ma cały jego kontekst, warto przywołać rzeczony fragment in extenso. Zdaniem Brunona skierowane do księcia żądanie świętych miało brzmieć następująco:

Similiter uiros, qui quamuis non bono animo occisis nobis hec bona dedere, illis non nocere, uxores et filios cum substancia eorum non disperdere, sed ut possint habere penitentiam et uitam conuertere eos in ęternum Dei seruicium ad sanctum locum oporteret ${ }^{20}$.

znajdzie się miejsce w jego klasztorze. Pozostałe argumenty (brak imienia przywódcy zabójców w treści VQF; posługiwanie się włócznią - rzekomo symbolem zarezerwowanym dla władzy książęcej; a nawet picie wina - według Stróżyka przywilej wysoko urodzonych, w istocie zaś treść stereotypowa, o czym: R. Kaiser, Trunkenheit und Gewalt im Mittelalter, Köln 2002, zwłaszcza s. 67-132, wynikająca z przekonania, iż alkohol wzmaga gniew i dodając odwagi, ułatwia popełnienie zbrodni. Zob. znaną definicję św. Izydora: „Ebrietas autem perturbationem gignit mentis, furorem cordis, flammam libidinis. Ebrietas ita mentem alienat, vt vbi sit, nesciat. Vnde etiam et malum non sentitur, quod per ebrietatem committitur", Sancti Isidori Hispalensis episcopi Sententiarum libri tres, red. F. Lorenzanae, w: Sancti Isidori Hispalensi episcopi Opera omnia, vol. 6, Roma 1802, lib. II, c. 43, s. 254, która wyraźnie koresponduje ze słowami Brunona) nie mają żadnej wartości dowodowej. Wszystkie zresztą argumenty tracą znaczenie w zderzeniu z informacją, iż inspirator zbrodni znał swe ofiary, gdyż wcześniej kazano mu, aby posługiwał eremitom (,in eorum servicio ministrare iussus fuit”, VQF, c. 13, s. 62). Nie ulega wątpliwości, iż w ten sposób można było określić tylko człowieka o niewysokiej kondycji społecznej, któremu powierzono zadanie pomagania na miejscu eremitom. Nie ma poparcia w źródle przypuszczenie P. Stróżyka, iż usługiwać mógł on pustelnikom tylko z rozkazu książęcego, a zatem wywodził się z otoczenia Chrobrego. Równie dobrze założyć można, iż do posługi posłał go lokalny urzędnik, któremu zapewne powierzono pieczę nad eremem, albo nawet biskup Unger, którego jurysdykcji podlegali eremici. Z tego powodu nie poznajemy imienia mordercy i jego towarzyszy ani żadnych dokładniejszych danych o tych osobach. Ich niski stan spowodował, iż Bruno nie odczuwał potrzeby bliższej charakterystyki tychże osób. Zdecydowanie należy w tym miejscu odrzucić także supozycję Marka Derwicha (Studia nad poczatkami monastycyzmu na ziemiach polskich. Pierwsze opactwa i ich funkcje, KH 107, 2000, 2, s. 85), iż przywódca morderców mógł być adwokatem klasztornym.W postkarolińskiej Europie możliwość sprawowania tej funkcji była zwykle pochodną wysokiej pozycji społecznej i prestiżu. Pełnienie adwokatury nie polegało natomiast na usługiwaniu, lecz sprawowaniu czynności prawnych oraz zabezpieczaniu dóbr klasztornych. Nic też nie wskazuje, by pustelnie posiadały defensorów. O przemianach w statusie adwokatów: M. Parisse, Advocate, Advocacy, w: Encyclopedia of the Middle Ages, vol.1, red. A. Vauchez, R. Dobson, M. Lapidge, Chicago 2000, s.20; Ch. West, The Significance of the Carolingian Advocate, „Early Medieval Europe” 17, 2009, 2, s. 186-206. Najbardziej prawdopodobne wydaje się, iż pierwotnie rola przywódcy morderców w relacji do eremitów przypominała tę kucharza Krystyna, o którym Bruno napisał: „eorum necessitati gratenter seruire solebat" (VQF, c. 13, s. 66).

${ }^{20} \mathrm{VQF}, \mathrm{c} .25$, s. 76. 
W tym twierdzeniu łatwo dostrzec, iż święci nie tylko domagać mieli się od księcia zmiany powziętej decyzji z powodu chrześcijańskiego wymogu udzielania zabójcom możliwości pokutowania, ale też w swym żądaniu precyzowali docelową formę ich pokuty. Została ona przez Brunona określona jako „ęternum Dei seruicium ad sanctum locum”. Okazuje się więc, iż w ramach ekspiacji zabójcy pełnić mieli dożywotnią służbę na rzecz Boga, a w praktyce - jak wolno dopowiedzieć - na rzecz klasztoru i mnichów.

Dalsza analiza problemu pokuty morderców powinna skupić się głównie na właściwym odczytaniu użytego przez Brunona sformułowania. Wyrażenie to z pewnością nie daje się łatwo zinterpretować na podstawie tekstu źródła. Nieco dopowiada tylko jeszcze jeden fragment Żywota. Mówi on, iż mordercy gotowi byli „usługiwać” w klasztorze poprzez wykonywanie różnych niezbędnych czynności: ,in illo monasterio [- - ] necessaria libenter seruire parati sunt" ${ }^{21}$. Nie wynika z tego jednak, jaki charakter miała mieć owa posługa.

Na pozór „,wieczna służba Bogu w świętym miejscu” wydaje się określeniem nieprecyzyjnym i niejasnym. Łatwo jedynie skonstatować, iż zgodnie $\mathrm{z}$ tradycją termin sanctus locus oznacza w tym przypadku klasztor ${ }^{22}$. Poza tym słowa Brunona moga jednak budzić rozliczne wątpliwości i prowadzić do rozbieżnych interpretacji. Pojawiające się głosy świadczą zresztą, iż historycy mieli poważne problemy z uchwyceniem ich sensu. Wyrażenie to zwróciło uwagę mediewistów obradujących podczas zdominowanej przez postulaty historiografii marksistowskiej Pierwszej Konferencji Metodologicznej Historyków Polskich. Spierano się wówczas nad tym, czy przekaz ów należy uznać za dowód istnienia w państwie Chrobrego „zależności feudalnej chłopów” względnie „włościańskiego poddaństwa”, czy też raczej niewolnictwa w gospodarce „wielkiej własności kościelnej”23. Powodem nieporozumień stał się obecny w Żywocie termin aeternum servitium,

${ }^{21}$ Ibidem, c. 13 , s. 65.

22 Por. A. Dimier, Le mot "locus” employé dans le sens de monastère, „Revue Mabillon” 58, 1972, s. 133-154; A. Dubourdieu, J. Scheid, Lieux de culte, lieux sacrés: les usages de la langue, w: Lieux sacrés, lieux de culte, sanctuaires, red. A. Vauchez, Rome 2000, s. 59-80.

${ }^{23}$ Pierwsza konferencja metodologiczna historyków polskich, t. 1, red. S. Herbst et al., Warszawa 1953. Za pierwszą opcją argumentował szczególnie Stanisław Arnold (s. 172), a poparł ten wniosek Henryk Łowmiański (s. 219). Przeciwnie wypowiedział się Tadeusz Manteuffel, nieprecyzyjne stwierdzając, iż w „prawie zachodnioeuropejskim zamieniano karę śmierci na niewolę" (s. 213). Juliusz Bardach zaznaczył z kolei, iż w Żywocie „niewola występuje w charakterze kary” (s. 247). Natomiast zupełnie niejasne stanowisko zajął Wojciech Hejnosz (s. 265). Do poglądu T. Manteuffla niewiele później przychylił się Henryk Grajewski, Kara śmierci w prawie polskim do połowy XIV wieku, Warszawa 1956, s. 108-108, przyp. 156. 
który interpretowano jednak w oderwaniu zarówno od kontekstu źródła, jak i zachodnich analogii. Chociaż Bruno wyraźnie położył nacisk na pokutny charakter służby zabójców, żaden z pochylających się wówczas nad źródłem mediewistów nie podjął nawet próby pokierowania analizy zgodnie z czytelną sugestią autora.

Do dziś więc przekaz ukrywa nierozpoznane treści. Trudność ich odczytania polega na tym, iż Kwerfurtczyk zilustrował interesującą nas kwestię, posługując się terminologią pochodzącą ze słownika monastycznego i kościelno-prawnego zarazem, której - jako oczywistej dla potencjalnych odbiorców - nie czuł się w obowiązku objaśniać. Dla zrozumienia świadectwa niezbędna okazuje się więc znajomość pojęć, którymi operował autor.Jako że dotychczas nikt nie zadał sobie trudu ich przebadania, na tej już tylko podstawie odrzucić trzeba dawne próby odczytywania terminu aeternum servitium w kategoriach „feudalnego uzależnienia” albo też niewolnictwa, choć w oparciu o brzmienie źródła dozwolone jest twierdzenie, iż miał to być rodzaj zesłania czy nawet niewoli, jednak w rozumieniu penitencjarnym czy raczej pokutnym.

Z wypowiedzi Kwerfurtczyka wynika, iż zastosowane przez niego terminy i sformułowania warto rozpatrywać na gruncie religijnym i karnym (prawnym), przy czym jednak trzeba mieć świadomość, iż w umyśle duchownego obie te sfery wzajemnie się przenikały.

Perspektywa pierwsza sprowadzić musi rozważania na grunt teologiczny. Termin servitium, a zwłaszcza servitium Dei w języku wczesnośredniowiecznego kleru posiadał wyraźne konotacje religijne. Do jego podstawowych znaczeń należała „służba Bogu”, pojmowana w sensie duchowym i eklezjalnym jako prowadzenie życia konsekrowanego, a więc toczenie nieustannej walki po stronie Boga, a przeciw siłom szatana (Deo militare). Każdy duchowny to wszak w wiekach średnich servus Dei, ten, który posiadał święcenia wyższe, także servus altaris. Analogiczny typ rozumowania miał jednak swą szczególną wagę w monastycyzmie. Dla mnichów wyrażenie servire Deo było jednoznaczne z ich codzienną posługą w klasztorze, najistotniejszym sensem życia klasztornego, dlatego też czarni mnisi to w źródłach często "fratres deo sub regula sancti Benedicti Deo servientes" lub „militantes” 24 . Taką interpretację terminu odziedziczyło średniowiecze po św. Augustynie, który w swych pismach wyrażenie owo utożsamiał właśnie z religijnymi zadaniami mnichów, podkreślając ich wycofanie ze

${ }^{24}$ Wymienne stosowanie terminów Deo servire i Deo militare potwierdzają dobrze źródła ottońskie: S. Wells, The Warrior Habitus: Militant Masculinity and Monasticism in the Henrician Reform Movement, w: Negotiating Clerical Identities: Priests, Monks and Masculinity in the Middle Ages, red.J.D. Thibodeaux, Basingstoke 2010, s. 62-64. 
świata i całkowite poświęcenie Bogu ${ }^{25}$. W jego mniemaniu życie w klasztorze nie miało w sobie jednak nic z niewoli, lecz było najwyższą formą wolności-wyzwolenia ${ }^{26}$. Myśl tę później skrzętnie podkreślano. Grzegorz Wielki, a za nim choćby Odo z Cluny, głosili nawet, iż wstąpienie w szeregi mnichów jest niejako uwolnieniem od niewoli życia świeckiego ${ }^{27}$. Tego rodzaju skojarzenia w X i XI w. wpojono wielu mnichom, także Brunonowi z Kwerfurtu. Wejść do służby pańskiej znaczyło dlań wszak tyle, co złożyć śluby zakonne; służyć Bogu, tyle co funkcjonować w ramach zgromadzenia mniszego lub w pustelni ${ }^{28}$. Odczytywanie słów Brunona w tym duchu prowadzi do wniosku, iż przekazanie zabójców do klasztoru ad aeternum Dei servitium miało także sens eschatologiczny. Możliwość pokuty poprzez służbę na rzecz Boga, w bliskości mnichów, sprawiła, iż zabójcy zostali wyrwani z objęć śmierci, nie tylko fizycznej, ale też duchowej, umożliwiała bowiem ich wewnętrzną przemianę, co wyraźnie pobrzmiewa w uzasadnieniu postulatu skierowanego do księcia: „ut possint habere penitentiam et uitam conuertere". Służąc w opactwie, mordercy zyskali najlepszą możliwość odpokutowania winy, stali się bowiem częścią wspólnoty, która miała silny kontakt z Bogiem i świętymi, a jej modły ogromną moc uwalniania od grzechu. Pomimo tego, iż popełnili straszliwą zbrodnię, dana została im szansa osiągnięcia życia wiecznego. Akt władcy niósł więc ze sobą dalekosiężne i wielce pozytywne skutki. Stojąca za nim decyzja doprowadziła bowiem nie tylko do odsunięcia wizji śmierci, uchowania rodzin skazańców przed ruiną, ale także nawrócenia grzeszników i przywrócenia im perspektywy zbawienia.

Mimo że duchowni niekiedy żądali od władców surowego traktowania agresorów godzących w cielesność osób zaliczanych do stanu duchowne-

${ }^{25}$ G.P. Lawless, An Augustine Glossary of Monastic Terms, w: Homo spiritualis: Festgabe für Luc Verheijen, red. C. P. Mayer, Würzburg 1987, s. 276-294.

${ }^{26}$ Sancti Aureliani Augustini Hipponensis episcopi Regula ad servos Dei, w: Sancti Aurelii Augustini Hipponensis episcopi Opera omnia, vol. 1, PL, vol. 32, c. 12, kol. 1384. Św. Augustynowi przypisuje się autorstwo maksymy „Deo servire vera libertas est”.

${ }_{27}$ S. Gregorii Magni Moralia in Job, red. M. Adriaen, w: Corpvs Christianorum. Series latina, vol. 143A, Turnhout 1979, lib. XVII, c. 13, s. 862-863; Odonis abbatis Cluniacensis Moralium in Job libri XXXV, PL, vol. 133, lib. XVII, c. 25, kol. 311-312; K. A. Smith, War and Making of Medieval Monastic Cullture, Woodbridge 2011, s. 13.

${ }^{28}$ „,habitum quem accepit, in Dei seruicio terminasset”, VQF, c. 2, s. 31; ,ad heremum Deo seruire regressus est”, c. 2, s. 33; „uir contemplator et uere seruus Dei”, c. 2, s. 35; „studebat si laicus, si clericus, maxime si seruus Dei”, c. 8, s. 48; „in Dei seruicio legitime militarent”, c. 9, s. 49; „Dei seruos in ills silva occiderent”, c. 13, s. 60; „facto monachorum, die ac nocte Deo seruiunt", c. 19, s. 70. Warto zaznaczyć, iż terminem traditio ad servitium Dei określano ofiarowanie oblatów: M. de Jong, In Samuel's Image. Child Oblation in Early Medieval West, Leiden 1996, s. 86. Por. też Glossarium mediae et infimae latinitatis, red. Ch. du Cange, t. 7, Niort 1886, kol. 448c, sv. servitium Dei. 
go, łaska, jaką wykazał się Bolesław Chrobry, mogła w tym wypadku zostać przyjęta z uznaniem. Do zadań duchownych należało interweniowanie na rzecz skazańców ${ }^{29}$, z tego też powodu gloryfikowali oni władców łaskawych i zdolnych do darowania win $^{30}$. Odstąpienie od decyzji ukarania śmiercią, nawet krzywdzicieli duchownych, mogło więc spotkać się z pochwałą ze strony mnichów jako szczytny akt monarszej łaski ${ }^{31}$. Dla celów porównawczych z piśmiennictwa monastycznego przywołać warto „Żywot św. Geralda z Aurillac” w wersji sfałszowanej przez Adémara z Chabannes (tzw. Vita prolixior) ${ }^{32}$. Tytułowy bohater, wcielony ideał cnót monastycznych, a po części też monarszych, zasłużył w tym dziele na pochwałę z dość niezwykłego powodu. Gdy mianowicie jego urzędnicy pochwycili i wtrącili do więzienia pewnego człowieka, winnego wyłupienia oczu prezbiterowi, Gerald tylko pozornie okazywał żywą chęć ukarania go, jednocześnie natomiast czynił starania, by kapłan zrezygnował z dochodzenia krzywdy. Co więcej, winnemu okrutnego czynu dostarczał pożywienie, podarował buty, a ostatecznie puścił wolno. W trakcie rozprawy sądowej, gdy okazało się, że więzień zniknął, Gerald stwierdzić miał jedynie, że właściwie dobrze się stało, albowiem rolą kapłana było przebaczyć swemu prześladowcy. Nie mogło jednakże obyć się bez zwyczajowej rekompensaty. Ten obowiązek wziął jednak Gerald na siebie,

${ }^{29}$ Badania ograniczały się głównie do analizy roli biskupów: L. Jégou, L’évêque, juge de paix: l'autorité épiscopale et le règlement des conflits entre Loire et Elbe (milieu VIII'-milieu XI siècle), Turnhout 2011, s. 328-341.

${ }^{30}$ Ażeby nie szukać daleko, przywołać warto opinię Anonima zw. Gallem o Bolesławie Chrobrym: Galli Anonymi Cronicae et gesta ducum sive principium Polonorum, wyd. K. Maleczyński, Kraków 1952, MPH s.n., t. 2, lib. I, c. 13, s. 33. Z tekstów czasowo bliższych twórczości Brunona na uwagę zasługuje Legenda Krystiana, a konkretnie pochwała św. Wacława z powodu odwoływania wyroków śmierci, burzenia szubienic i zamykania więzień: Vita et passio sancti Wenceslai et sancte Ludmile ave eius, red. J. Ludvíkovský, Praha 1978, c. 6, s. 54. Por. J. Nastalska-Wiśnicka, Rex martyr. Studium źródłoznawcze nad legenda hagiograficzna św. Wacława, Lublin 2010, s. 262.

${ }^{31}$ Konieczność okazywania łaski przez władców była w tym czasie żywym ideałem w domenie ottońsko-salickiej, o czym S. Weinfurter, Herrschen durch Gnade. Legitimation und Autorität des Königtums in ottonisch-frühsalischer Zeit, w: Forschungsbeiträge der Geisteswissenschaftlichen Klasse, red. E. Hlawitschka, München 2009, s. 109-126.

${ }^{32}$ BHL 3411. W sposób niebudzący wątpliwości fałszerstwo tej wersji Vitae Geraldi wykazał dopiero niedawno Mathew Kuefler, Dating and Authorship of the Writings about Saint Gerald of Aurillac, „Viator” 44, 2013, 2, s. 49-97. Na temat ideału reprezentowanego przez św. Geralda zob. F. Lotter, Laienfrömmigkeit in den Anfängen Clunys: Odos Vita des Grafen Gerald von Aurillac, w: Benedictine Culture, 750-1050, red. W. Lourdaux, Louvain 1983, s. 76-95; A.-M. Bultot-Verleysen, L'évolution de l'image de Géraud d'Aurillac (†909), seigneur laïque et saint, au fil de ses trois „vitae”, w: „In principio erat verbum”. Mélanges offerts en hommage à Paul Tombeur, red. B.-M. Tock, Turnhout 2005, s. 45-92. 
darując poszkodowanemu jeden ze swoich kościołów, jak wolno się domyślić, głównie dlatego, iż oprawcy nie posiadali majątku ${ }^{33}$.

W opisie Kwerfurtczyka mamy w gruncie rzeczy do czynienia ze zbliżoną sytuacją. Choć książę Bolesław skazał morderców na dożywotnią pokutę, to jednocześnie uwalniał ich od śmierci czy dożywotniego więzienia $^{34}$, ofiarowując im najwyżej cenioną odmianę wolności, w znaczeniu monastycznym - wolności od świata (libera custodia). Poza tym jego decyzja zawierała także wyraźny charakter odszkodowawczy. Władca podarował owych zabójców instytucji kościelnej kontynuującej tradycję eremu. Akt ten był więc jednocześnie formą donacji ze wszystkimi konsekwencjami i duchowymi kontekstami tej czynności ${ }^{35}$. Z tego powodu ekspiację morderców, ludzi z pewnością niezamożnych, poprzez ich wkład pracy w funkcjonowanie opactwa, można postrzegać jednocześnie jako formę pokuty, jak i moralnej oraz materialnej rekompensaty (emendatio, satisfactio) ${ }^{36}$.

Określenie penitencji morderców przy pomocy sformułowania ,aeternum Dei servitium ad sanctum locum" daje również wyraźne przesłanki, by móc sądzić, iż za umieszczeniem zabójców w klasztorze stały też czynniki o charakterze penitencjarnym. Odczytanie tych prawnych aspektów wydaje się nawet znacznie istotniejsze dla prawidłowego zinterpretowania Brunonowego przekazu oraz zrozumienia losu, jaki spotkał morderców. Pokuta w okresie wczesnego średniowiecza, w tym około 1000 r., posiadała oczywisty wymiar prawny, wynikający z kształtujących jej for-

${ }^{33}$ Vita sancti Geraldi Auriliacensis comitis, PL, vol. 133, c. 19, kol. 634-635.

${ }^{34}$ Według Damianiego (VBR, c. 28, s. 64) Chrobry wahał się, czy skazać morderców na śmierć. Postulat zamiany kary śmierci na pokutę pojawia się niekiedy w prawodawstwie. Zob. T. P. Oakley, The Cooperation of Mediaeval Penance and Secular Law, ,Speculum" 7, 1932, 4, s. 524. Najbardziej znany przepis tego typu został wydany przez Karola Wielkiego: „Si vero pro his mortalibus criminibus latenter commissis aliquis sponte ad sacerdotem confugerit et confessione data ageri poenitentiam voluerit, testimonio sacerdotis de morte excusetur", Capitulatio de partibus Saxoniae, wyd. A. Boretius, MGH Capitularia regum Francorum, t. 1, Hannoverae 1883, c. 14, s. 69.

${ }^{35} \mathrm{Na}$ temat rozmaitych sensów donacji E. Magnani, Du don aux églises au don pour le salut de l'âme en Occident (IV $-X I^{e}$ siècle), w: Pratiques de l'eucharistie dans les Églises d'Orient et d'Occident, t. 2, red. N. Bériou, B. Caseau, D. Rigaux, Paris 2009, s. 1021-1042.

${ }^{36}$ W kwestii wymogu odszkodowania za krzywdę wyrządzoną duchownemu R. Kotecki, ,...id est omnis sacrae rei violatio”. Świętokradztwo w świetle anonimowego Traktatu de sacrilegiis et immunitatibus et eorum compositionibus z końca XI wieku, St. Źr. 48, 2010, s. 15-38. Z przepisów synodalnych np. „Ut saeculares, qui de catalogo clericorum aliquem occiderint vel castraverint, vel aliquo membro detruncaverint, seu temere dehonestaverint, et de praeteritis poenitendo ecclesiae satisfaciant, et emendare studeant", Concilium Viennense [a. 892], wyd. J. D. Mansi, w: Sacrorum conciliorum nova et amplissima collectio, vol. 18/1, Venetiis 1773, c. 2, kol.121. Podobne zarządzenia pojawiały się wielokrotnie. 
my dokumentów normatywnych, takich jak ustawy synodalne, kapitularze lub regulacje penitencjałów ${ }^{37}$. Teksty te przewidywały rozmaite rodzaje sankcji, wśród nich także pokutę, którą penitent miał realizować w klasztorze.

Podejrzewać należy, iż owa tradycja mogła wywrzeć wpływ na decyzję księcia Bolesława. Istnienie w Europie Zachodniej zwyczaju zsyłania w mury klasztorów osób winnych rozmaitych przestępstw powinna skłaniać do podjęcia próby zidentyfikowania kary, którą ostatecznie nałożono na sprawców morderstwa i profanacji eremu, jako rodzaju „pokuty klasztornej" (Klosterbuße, monastic penance).

Choć wspomniana forma penitencji jest słabo potwierdzona w źródłach pokarolińskich, a niemal zupełnie nieodnotowana w świadectwach spisanych na terenach Europy Środkowej we wcześniejszych fazach średniowiecza, należy brać pod uwagę okoliczność, iż brak źródeł porównawczych z danego terytorium nie musi przekreślać zasadności zasygnalizowanej interpretacji. Klasztor jako miejsce odosobnienia, modlitwy, ale też ekspiacji nadawał się doskonale do tego, by winny zbrodni, mógł w jego murach pędzić żywot pokutniczy ${ }^{38}$.Życie mnichów przepełniały wszak gesty właściwe dla rytuałów pokuty publicznej, która zresztą wyewoluowała ze zwyczajów monastycznych ${ }^{39}$. Mnisi żyli poza tym niejako poza światem doczesnym jak ludzie odsunięci od społeczeństwa. Ekspiacyjny charakter życia klasztornego wzmacniały dodatkowo zalecenia reguł i consuetudines wyliczające przewiny mnichów, które wymagały odkupienia na drodze realizacji szczegółowo opisanych aktów pokutnych ${ }^{40}$.

Chcąc jednak uzyskać lepszy kontekst dla świadectwa Brunona, należy odwołać się do źródeł zachodnioeuropejskich. Mayke de Jong oraz

${ }^{37}$ R. Meens, Penitentials and the Practice of Penance in the Tenth and Eleventh Centuries, „Early Medieval Europe” 14, 2006, 1, s. 7-22. Z licznych prac poświęconych pokucie zob. S. Hamilton, The Practice of Penance, 900-1050, London 2001; L. Körntgen, Canon Law and the Practice of Penance: Burchard of Worms's Penitential, „Early Medieval Europe” 14, 2006, 1, s. 103-118; A. Firey, Useful Guilt: Canonists and Penance on the Carolingian Frontier, w: Readers, Texts, and Compilers in the Earlier Middle Ages, red. M. Brett, K. G. Cushing, Aldershot 2008, s. 15-33; A. Grimm, Zwischen Gottes Gericht und irdischem Strafrecht. Strafe und Buße in Lebensbeschreibungen ottonisch-salischer Reichsbischöfe, Stuttgart 2011.

${ }^{38}$ M. de Jong, In Samuel's Image, s. 129-130.

39 S. Hamilton, op. cit., s. 77-103.

${ }^{40} \mathrm{H}$. Lutterbach, Die Klosterbuße am Übergang von der Spätantike zum Frühmittelalter, „Zeitschrift für Kirchengeschichte” 106, 1995, s. 56-69; N. Pancer, „Crimes et châtiments” monastiques: aspects du système pénal cénobitique occidental ( $V^{e}$ et $V^{e}$ siècles), „La Moyen Âge" 109, 2003, s. 261-276; V. Passarini, La penitenza nelle regole monastiche medievali occidentali, „Rivista liturgica” 92, 2005, s. 715-736; M. Ch. Giorda, La direction spirituelle à travers les règles monastiques. Péchés, pénitence et punitions dans le monachisme pachômien, „Collectanea Christiana Orientalia” 6, 2009, s. 95-113. 
Guy Geltner wyraźnie pokazali, iż pokuta klasztorna największe znaczenie zyskała w państwach frankijskich. Za panowania władców merowińskich, a szczególnie Karolingów, wraz z upowszechnieniem zasad monastycyzmu iryjskiego, umieszczanie złoczyńców w klasztorach stało się zjawiskiem stosunkowo częstym, a twórcy źródeł prawnych z tego okresu regularnie wypowiadali się o klasztornej formy penitencji. Istotny głos w tej materii mieli także władcy, posiadający znaczne wpływy w sferze eklezjalnej. Nie tylko obwarowywali ową sankcją niektóre przestępstwa w swoich kapitularzach, ale też zsyłali przestępców, a często nawet swych wrogów politycznych, w mury opactw, które sami kontrolowali ${ }^{41}$. Wraz z dekadencją władzy Karolingów i postępującym równolegle zamieraniem stworzonych przez nich ram prawnych omawiany rodzaj pokuty ulegać zaczął pewnej marginalizacji, jednakże nie zaniknął.

Istotniejsze dla niniejszych rozważań jest jednakże spostrzeżenie, iż $\mathrm{w}$ tradycji pokutnej znany był zwyczaj umieszczania w klasztorach przestępców, którzy okazali się winni fizycznej napaści na osobę duchowną, zwłaszcza zabójstwa. Niestety praktyka ta poświadczona jest niemal wyłącznie przez przepisy penitencjałów. Brzmienie tych norm jest jednak na tyle interesujące, iż warto poświęcić im nieco uwagi. To, co szczególnie uderza w ich treści, to fakt, iż w ramach przewidywanej sankcji przepisy pokutne nakazywały nie tyle po prostu zamykać agresorów w konwentach, ile raczej obligowały do pokutowania poprzez odbywanie służby „służby Bogu", a więc dokładnie tak, jak opisał to Bruno. Najstarszy przepis dający zaliczyć się do tej tradycji pochodzi z tzw. Kanonów lub Wyroków Teodora (VII), jednej z popularniejszych kompilacji na kontynencie pomiędzy VIII a X w. Jeden z przepisów tego zbioru stanowi: „Kto zabiłby mnicha lub duchownego, niech złoży broń i służy Bogu, albo pokutuje przez 7 lat" ${ }^{42}$. Użyte w tym przepisie wyrażenie Deo serviat na określenie pokuty oznacza niewątpliwie posługę w klasztorze. Uprawnia do takiej konkluzji nie tylko późniejsza tradycja, ale też inny przepis z tego samego zbioru, w którym św. Teodor zalecił, by porywacz mnicha w ramach po-

${ }^{41}$ M. de Jong, What Was Public about Public Penance? Paenitentia publica and Justice in the Carolingian World, w: La giustizia nell'alto medioevo, secoli IX-XI, Spoleto 1997, s. 863-904; eadem, Monastic Prisoners of Opting Out? Political Coercion and Honour in the Frankish Kingdoms, w: Topographies of Power in the Early Middle Ages, red. M. de Jong, F. Theuws, Leiden 2001, s. 291-328; G. Geltner, Detrusio. Penal Cloistering in the Middle Ages, „Revue bénédictine” 118, 2008, s. 89-108.

${ }_{42}$ „Si quis occiderit monachum vel clericum arma relinquere et deo serviat vel VII annos peniteat in iudicio episcopi est", Iudicia Theodori Cantuariensis, wyd. P.W. Finsterwalder, w: Die Canones Theodori Cantuariensis und ihre Überlieferungsformen, Weimar 1929, c. 1, 4, 5, s. 294. 
kuty służył Bogu w klasztorze ${ }^{43}$. Na tej tylko podstawie zbieżność treści przepisów z określeniem losu zabójców Pięciu Braci wydawać może się jedynie przypadkiem. Należy mieć jednak na uwadze wzgląd, iż uregulowanie autorstwa św. Teodora było powielane przez licznych autorów ksiąg pokutnych tworzących później oraz co za tym idzie szeroko rozpropagowane na kontynencie w okresie karolińskim i X w. ${ }^{44}$ Szczególną

43 „Laicus de monasterio monachum furtum discesserit, [- $]$ in tret in monasterium Deo servire", Capitula Dacheriana, wyd. P. W. Finsterwalder, w: Die Canones Theodori, c. 92, s. 246. Przepis znany także z innych penitencjałów: Poenitentiale [Pseudo-]Cummeani, wyd. F. W.H. Wasserschleben, w: Die Bußordnungen der abendländischen Kirche, Halle 1851, c. IV/8, s. 476; Discipulus Umbrensium, w: Księgi pokutne, oprac. A. Baron, H. Pietras, Kraków 2011, c. III/1, s. 135.

${ }^{44} \mathrm{~W}$ formie identycznej przepis powtórzono w Poenitentiale Bedae, wyd. F. W. H. Wasserschleben, w: Die Bußordnungen, c. VI/1, s. 224; Poenitentiale Pseudo-Bedae, wyd. F.W.H. Wasserschleben, w: Die Bußordnungen, c. XIII/1, s. 265; Poenitentialae Cummeani, wyd. H.J. Schmitz w: Die Bussbucher und die Bussdisciplin der Kirche, Mainz 1883, c. VI/4, s. 630. Tekst wzbogacony m.in.: „Si quis monachum vel clericum occiderit, arma relinquat et Deo se rviat vel VII annos poeniteat. In judicio episcopi est. Qui autem episcopum vel presbyterum occiderit, regis judicium est de eo", Poenitentiale Theodori, wyd.F.W.H. Wasserschleben, w: Die Bußordnungen, c. IV/5, s. 188; „Qui episcopum aut presbyterum occidit, regi dimittendus est ad judicandum; qui occidit monachum vel clericum, in judicio episcopi est, vel arma relinquat et deo serviat, licet VII annos peniteat”, Theodorus, Canones Gregorii, w: Die Bußordnungen, c. 108, s. 172; „Qui aepiscopum occiderit, arma relinquat et XIII annis exul in pane et aqua poeniteat, vel secundum placitum universalis concilii, semper poeniteat, et instanter D e o s e r viat", Poenitentiale Pseudo-Theodori, wyd. F. W. H. Wasserschleben, w: Die Bußordnungen, c. III/5, s. 569, oraz „Qui presbiterum occiderit, arma relinquat, XII annis in pane et aqua poeniteat, et semper De o serviat”, ibidem, c. 6; „Si homo quis monachum vel clericum occiderit, arma relinquat et $\mathrm{D}$ e o s e rviat, vel X annos jejunet; et id est episcopi judicium", Poenitentialae Pseudo-Egberti, wyd. F.W.H. Wasserschleben, w: Die Bußordnungen, c. LXVIII/20, s. 345; „Si quis episcopum vel presbyterum occiderit, id ad regis judicium, vel episcopi. Quicunque sacerdotem vel monachum occiderit, id est juris episcopi, utrum arma deponat et in monasterium eat, an VII annos jejunet", Confessionale Pseudo-Egberti, wyd. F. W.H. Wasserschleben, w: Die Bußordnungen, c. 23, s. 310; „Qui monachum vel clericum occiderit, juxta indulgentiam novi testamenti arma relinquat et De o s e rviat vel VII annis poeniteat", Poenitentiale Bigotianum, wyd. F. W. H. Wasserschleben, w: Die Bußordnungen, c. IV/2, s. 453, oraz „Qui episcopum vel presbyterum occiderit, regis judicium de eo est”, ibidem, c. 3; "Qui occiderit episcopum aut presbyterum vel diaconum, regio dimittendum est ad judicandum. Qui occiderit minoris ordinis clericum, in judicio episcopi est judicandus, ut arma relinquat et in monaste rio De o s e rviat, vel septem annos cum luctu poeniteat", Poenitentiale Pseudo-Gregorii III, wyd. F. W. H. Wasserschleben, w: Die Bußordnungen, c. 3, s. 538; „Si quis occiderit episcopum vel presbyterum vel diaconum vel clericum vel monachum, omnia derelinquat et De o s e rviat", Poenitentiale Cassinense, wyd. H.J. Schmitz, w: Die Bussbucher, c. 5, s. 402; „Si quis occiderit episcopum vel presbyterum, regi dimittendus est ad judicandum. Qui occiderit monachum vel clericum, judiciuim episcopi est, arma relinquat et D e o s e $\mathrm{r}$ vi at vel X sive XII annos paeniteat", Judicia Cummeani, wyd. H.J. Schmitz, w: Die Bussbucher, c. I/2, s. 654-655. 
rolę w upowszechnieniu normy odegrał tzw. Benedykt Lewita, który połączył przepis autorstwa arcybiskupa Canterbury z treścią kapitularzy Karola Wielkiego, tworząc dwie zupełnie nowe ustawy, których autorstwo przypisał cesarzowi Franków ${ }^{45}$. Ich treść jest o tyle istotna, iż z wypowiedzią autora Żywota Pięciu Braci łączy ją jeszcze jeden wspólny element. Otóż według obu autorów wymóg klasztornej służby pokutnej za zamordowanie mnicha miał obejmować cały okres życia mordercy (,ęternum Dei servitium ad sanctum locum"; ,in monasterio diebus vitae suae sub ardua poenitentia Deo serviat"). Z penitencjałów tylko współczesny Lewicie kompilator Poenitentiale Pseudo-Theodori zaznaczył, iż pokuta trwać winna dożywotnio (,semper poeniteat, et instanter Deo serviat”, por. przyp. 44), aczkolwiek treść pozostałych raczej również sugeruje takie rozwiązanie, tyle że nie explicite. Fakt ten, a także szeroka znajomość normy zapoczątkowanej przez św. Teodora każą sądzić, iż Bruno zinterpretował los morderców pustelników przez pryzmat przywołanych przepisów. Można się jedynie zastanawiać, czy norma ta znana była jeszcze w początkach XI w. i czy Bruno rzeczywiście mógł się z nią zaznajomić.

I ta kwestia daje się rozstrzygnąć. Istnieją świadectwa potwierdzające fakt, iż posługiwano się nią w państwie wschodniofrankijskim za ostatniego Karolinga oraz już po wymarciu dynastii. Sfabrykowane przez Lewitę kapitularze przytoczono in extenso pośród ustaw uchwalonych na wielkim synodzie odprawionym w 909 r. w Trosly, którego kanony po wielekroć w X i XI w. powielano ${ }^{46}$. Także siedem lat później na zgromadzeniu obradującym w Hohenaltheim pod egidą króla Konrada I zatwierdzono przepis o podobnym brzmieniu. Jego autorzy musieli znać ustawę przypisaną Karolowi Wielkiemu. Stwierdzali bowiem, iż jeśli ktoś podniesie rękę na biskupa, podpali lub zniszczy świątynię, zabije kapłana, mnicha albo blis-

${ }^{45}$ "Qui occiderit monachum aut clericum, arma relinquat, et De o in monasterio serviat cunctis diebus vitae suae, nunquam ad seculum reversurus, et septem annos publicam poenitentiam gerat", Benedicti diaconi capitularia spuria, wyd. G. H. Pertz, MGH Leges, t. 2, cz. 2, Hannoverae 1837, lib. II, c. 90, s. 78, oraz: „Si quis sacerdotem, vel levitam, aut monachum interfecerit vel debilitaverit, iuxta statuta priorum capitulorum quae Legi Salicae sunt addita componat; et insuper bannum nostrum, id est, sexaginta solidos, nobis persolvat, et arma relinquat, atque in monasterio diebus vitae suae sub ardua poenitentia Deo serviat, nusquam postmodum seculo vel secularibus militaturus, neque uxori copulaturus", ibidem, lib. II, c. 98, s. 78.

${ }^{46}$ Concilium Troslejanum, wyd. D. Mansi, w: Sacrorum conciliorum, vol. 18/1, c. 13, kol. 300-301. Szerzej na temat synodu i uchwalonych wówczas przepisów zwłaszcza G. Schmitz, Das Konzil von Trosly (909). Überlieferung und Quellen, „Deutsches Archiv für Erforschung des Mittelalters" 33, 1977, s. 341-434. 
ką sobie osobę, ma pokutować „in uno loco, id est monasterio, omnibus diebus vitae suae" 47 . Poza tym w X w. analogiczne uregulowanie funkcjonowało również w państwie zachodniofrankijskim. Arcybiskup Reims Fulko na krótko przed swą śmiercią z rąk zabójców (900) uchwalił na zwołanym przez siebie synodzie prowincjonalnym, iż mordercy kapłanów oraz okaleczający sługi Boże powinni zostać pozbawieni możliwości noszenia pasa rycerskiego, zmuszeni do oddalenia żon i wstąpienia do klasztoru, aby tam oddawać się „,sztuce pokutowania”. Penitencja ta miała obejmować zapewne cały okres życia, skoro przepis podkreślał, iż sprawcom wolno przyjąć Komunię Świętą dopiero na łożu śmierci ${ }^{48}$. Na tej podstawie sądzić można, że normy te były w stałym użyciu przez następne dekady po ostatecznym rozpadzie imperium karolińskiego. Podobny wniosek wypływa poza tym z badań G. Geltnera, który zaobserwował, iż powołana do życia forma penitencji traciła na popularności bardzo powoli. Równolegle tworzone i powielane normy pozwalają także sądzić, że sankcja pokuty w klasztorze ewoluowała raczej w kierunku luźno sprecyzowanego zwyczaju $^{49}$. Taki zwyczaj był na przełomie X i XI niewątpliwie znany. Dla przykładu przywołać można opinię Burcharda z Wormacji, który w swym Dekrecie (przed 1023) zalecał szafarzom pokuty, iżby przepisów dotyczących morderców nie trzymali się zbyt kurczowo, lecz kierowali się miłosierdziem. Przypominał jednak, iż niektóre regulacje w ramach pokuty za zabójstwo postulują porzucenie życia świeckiego i dożywotnią służbę Bogu w klasztorze ${ }^{50}$. Z Żywota św. Romualda autorstwa Damianiego wnioskować można nawet, że praktyka pokutowania w klasztorze nie była obca eremitom romualdiańskim. Wśród nich krążyła przecież wiadomość, iż sam założyciel eremu w Pereum przekroczył w młodości progi klasztoru celem

${ }^{47}$ Hohenaltheim, 20. September 916, wyd. E.-D. Hehl, H. Fuhrmannm, MGH Concilia, t. 6, cz. 1, Hannoverae 1987, c. 24, s. 31.

${ }^{48}$ Statut ten wydał Rudolf Pokorny, Neue Texte zur kirchlichen Gesetzgebung der Jahre um 900 aus der Reimser Kirchenprovinz, „Deutsches Archiv für Erforschung des Mittelalters” 52, 1996, s. 503-504: „Interfector etiam presbiterorum, sicut in synodo beato Bonefatio presidente iuxta decretalia sanctorum patrum et statuta canonum spiritu dei conditorum id sancitum est et decretum: Si quis talis, quod minime credimus, invenitur in occisione presbiteri vel debilitatione ministrorum dei, cingulum militare nullomodo habere pręsumat, sed in monasterio trusus artę poenitentiae poenas luat et nullomodo coniugio copuletur et a sacra communione privatus in fine mortis tantum viatico salutis fruatur, et cetera". Ponadto badacz odnalazł rękopis, który świadczy, iż przepis został powtórnie uchwalony na jakimś synodzie zorganizowanym w X w. Trudno jednak o jego jednoznaczną datację.

${ }^{49}$ G. Geltner, op. cit., s. 105-106.

50 „Si quis [- ] homicidium fecerit, seculum relinquat, et ingrediatur monasterium monachorum et ibi jugiter Deo serviat", Burchardi Wormaciensis ecclesiae episcopi Decretorum libri viginti, PL, vol. 140, lib. XIX, c. 5, kol. 952. 
ekspiacji winy, gdyż towarzyszył ojcu, kiedy ten pozbawił życia jednego ze swych nieprzyjaciól ${ }^{51}$.

Skoro istniała tradycja skazywania zabójców na pokutę w klasztorze, a nawet wiele przepisów, które postulowały tym rodzajem pokuty karać winnych śmierci mnicha czy też profanacji miejsca świętego, zakładać należy, że słowa Brunona z Kwerfurtu nie są jedynie trawestacją owych norm, ale echem rzeczywistej decyzji, jaką podjął Bolesław Chrobry, niewiele wcześniej umieszczając zbrodniarzy w ufundowanym przez siebie konwencie. Prawdopodobieństwa nabierają też podejrzenia, iż książęcy wyrok mógł zostać oparty na zachodnich przepisach regulujących właściwą formę penitencji za przestępstwo, którego dopuścili się mordercy eremitów.

Konkluzję tę daje się mocno ugruntować. Nie podważa jej generalnie słuszny wniosek, że administracja pokutą przynależała do kompetencji zarezerwowanych dla kapłanów i biskupów ${ }^{52}$. W państwach frankijskich do klasztorów zsyłali przestępców także władcy. Nie jest nawet przesadą stwierdzenie, iż niektórzy z nich postrzegali swe opactwa jako quasi-więzienia ${ }^{53}$. Poza tym można wskazać na władców, którzy aktywnie współuczestniczyli w tworzeniu norm pokutnych uwzględniających podobne rozwiązania. Był to efekt zachodzenia na siebie uprawnień monarchów jako najwyższych decydentów zarówno w sferze świeckiej, jak i kościelnej ${ }^{54}$, głównie Karola Wielkiego, który - jak wykazała Abigail Firey - dążył usilnie do integracji „systemu sądowego” z kościelnym „systemem penitencjarnym" 55 . W tym kontekście na szczególną uwage zasługuje przepis włączony do najsłynniejszego kapitularza tego Karolinga, Admonitio generalis z $789 \mathrm{r}$. W nim to władca zalecał, by sprawców szczególnie niegodziwych zbrodni umieszczać „in uno loco”, ażeby tam jako servientes w ramach ekspiacji win znosili trud pracy i służby według przepisów kanonicznych. Ostatni człon zarządzenia nie pozostawia najmniejszych wątpliwości, iż właściwym miejscem realizowania naka-

51 „pęnitentiam tanti reatus accępit, moxque ad monasterium [- - ] more homicidarum diebus XL permansurus in luctibus, properavit”, VBR, c. 1, s. 15.

${ }^{52}$ W Polsce recypowano normy zachodnie, o czym świadczy tekst z Liber Officiorum księżnej Matyldy. Por. B. Bolz, Obrzęd pokuty według kodeksu króla Mieszka II, „Studia Gnesnensia" 6, 1981, s. 261-275.

${ }^{53}$ W. Laske, Zwangsaufenthalt im frühmittelalterlichen Kloster, ,Zeitschrift der Savigny-Stiftung für Rechtsgeschichte. Kanonistische Abteilung” 64, 1978, s. 321-330.

${ }^{54}$ G. Brunel, La justice du roi de France vers l'an Mil, w: La justice en l'an Mil, red. C. Gauvard, Paris 2003, s. 27-52; R. Deutinger, Der König als Richter, w: Recht und Gericht in Kirche und Welt um 900, red. W. Hartmann, A. Grabowsky, München 2007, s. 31-48.

${ }^{55}$ A. Firey, op. cit., s. 31-32; eadem, A Contrite Heart: Prosecution and Redemption in the Carolingian Empire, Leiden 2009, s. 212. 
zanej pokuty miał być klasztor. Taka konkluzja wydaje się też oczywista w świetle istniejącej już wówczas tradycji pokutnej, jak i zastosowanej terminologii $(\text { locus }=\text { monasterium })^{56}$.

W zgodzie z tym duchem panujący zalecać mogli pokutę w swoich prawach. Najlepszym tego przykładem wydają się zwody anglosaskie czerpiące wyraźnie z rozwiązań karolińskich. W nich to, począwszy od praw króla Alfreda, pokuta funkcjonowała jako zamiennik niektórych kar lub też ich ważne dopełnienie ${ }^{57}$. Co istotniejsze, zbliżoną sytuację obserwować możemy także w dekretach króla Węgier, św. Stefana, dotyczących zabójców ${ }^{58}$.

Znane są poza tym świadectwa współdecydowania władców o losie osób, które zaatakowały osobę duchowną. Warto przywołać dwa wschodniofrankijskie przykłady zbliżone do podejmowanej kwestii. Na wspomnianym synodzie w Hohenaltheim król Konrad I wraz z biskupami wydał wyrok dożywotniej pokuty w klasztorze względem grafa Erchangera oraz jego kompanów za to, że ci dopuścili się brutalnego aktu przemocy wobec biskupa Konstancji i opata Sankt Gallen, Salomona ${ }^{59}$. Podobny wyrok w 999 r. zatwierdzili wspólnie Otto III i Sylwester II wobec Arduina z Ivrei, gdyż ludzie hrabiego na jego rozkaz napadli na świątynię biskupią w Vercelli, doszczętnie ją zniszczyli i, co gorsza, brutalnie zamordowali jej pasterza ${ }^{60}$.

56 „si aliquid inconsuetum et capitale crimen conmiserint, ut in uno loco permaneant laborantes et servientes et poenitentiam agentes secundum quod sibi canonice inpositum sit", Admonitio generalis, 789. m. Martio 23., wyd. A. Boretius, MGH Capitularia regum Francorum, s. 60-61. Por. D. Iogna-Prat, Topographies of Penance in the Latin West, w: A New History of Penance, red. A. Firey, Leiden 2007, s. 153.

${ }^{57}$ T.P. Oakley, op. cit., s. 515-524; C. A. Hough, Penitential Literature and Secular Law in Anglo-Saxon England, „Anglo-Saxon Studies in Archaeology and History” 11, 2000, s. 133-141; C. Cubitt, Bishops and Councils in late Saxon England: the Intersection of Secular and Ecclesiastical Law, w: Recht und Gericht, s. 151-168; S. Jurasinski, Violence, Penance, and Secular Law in Alfred's Mosaic Prologue, „Haskins Society Journal” 22, 2011, s. 28-29.

${ }^{58}$ Decreta S. Stephani regis, w: Decreta Regni mediaevalis Hungariae, wyd. i przeł. J. M. Bak, J. R. Sweeney, Idyllwild 1999, lib. I, c. 14-15, s. 4-5.

59 „hanc pęnitentiam iniunximus, ut seculum relinquant, arma deponant, in monasterium eant, ibi iugiter pęniteant omnibus diebus vitae suae", Hohenaltheim, 20. September 916, c. 21, s. 27-28. Na temat synodu i roli władcy w przedsięwzięciu M. Hellmann, Die Synode von Hohenaltheim (916). Bemerkungen über das Verhältnis von Königtum und Kirche im ostfränkischen Reich zu Beginn des 10.Jahrhunderts, „Historisches Jahrbuch” 73, 1954, s. 127-142; H. Fuhrmann, Die Synode von Hohenaltheim (916) - quellenkundlich betrachtet, „Deutsches Archiv für Erforschung des Mittelalters” 43, 1987, s. 440-468; W. Hartmann, König Konrad I. und die Kirche, w: Konrad I. auf dem Weg zum „Deutschen Reich"?, oprac. H.-W. Goetz, Bochum 2006, s. 93-109.

${ }^{60}$ Ottonis III et Silvestri II synodus Romana (999), wyd. L. Weiland, MGH Constitutiones et acta publica imperatorum et regum, t. 1, Hannoverae 1893, s. 53; H. Zimmermann, Papstregesten 911-1024, Wien 1998, nr 862; S. Hamilton, op. cit., s. 1-2, 7-8, 13, 173, 207-208; eadem, Inquiring into Adultery and Other Wicked Deeds: Episcopal Justice in Tenth 
Z powodu ważkich analogii warto także zwrócić uwagę na pewne źródło walijskie, a mianowicie sui generis sprawozdanie włączone do „Księgi z Llandaff". Interesująco zrelacjonowano w nim działania biskupa Glamorgan, Padarna (943-961), podjęte w odpowiedzi na brutalne morderstwo miejscowego diakona (955). Duchowny ten padł ofiarą ludzi powiązanych z dworem króla Gwentu, Noguiego (ok. 950-ok. 970), którzy zamordowali go, pomimo iż diakon schronił się w kościele św.św. Germana i Febrica (prepozytura opactwa św. Teilona), tuż przy samym ołtarzu. Według źródła biskup, dowiedziawszy się o tych wypadkach, wysłał posłów do wszystkich podległych sobie klasztorów i kościołów z poleceniem stawienia się ich rządców na synod. W jego trakcie obłożono sprawców zbrodni, ale też ich pana, ciężką klątwą. Jednakże król nie zamierzał wcale torpedować decyzji biskupa, lecz idąc za opiniami doradców, postanowił zaprosić Padarna do Gwentu, by w swej stolicy wraz z dostojnikami królestwa, wspólnie $z$ ordynariuszem uregulować palącą kwestię. Zorganizowano więc drugi synod, na którym uradzono, co należy uczynić z mordercami. Decyzje, jakie zapadły w trakcie tego zgromadzenia oraz decyzje uzupełniające wydane później, wydają się niezmiernie istotne w kontekście losu, jaki według Kwerfurtczyka spotkał zabójców eremitów. Otóż biskup i władca, kierując się radami „doktorów” (a więc zapewne ludzi biegłych w prawach), zadecydowali najpierw, aby mordercy diakona zostali zamknięci w klasztorze św. Teilona i tam przebywali przez sześć miesięcy. Natomiast po tym czasie, zgodnie z dezyderatem przedłożonym przez króla, zostali oni ostatecznie przekazani do prepozytury, w której dokonane zostało morderstwo, aby tam - jak zapisano - „przyjęli osąd Boga”. Następnie zapadła zgodna decyzja co do tego, aby każdy z oprawców oddał owej instytucji cały posiadany majątek ziemski oraz ruchomości, a poza tym wszyscy wypłacili cenę kwoty jak za swój wergeld, co należy interpretować jako wykupienie się od kary śmierci ${ }^{61}$.

and Early Eleventh-Century Italy, „Viator” 41, 2010, 2, s. 35-36. Por. też R. M. Dessì, La double conversion d'Arduin d'Ivrée: Pénitence et conversion autour de l'An Mil, w: Guerriers et moines. Conversion et sainteté aristocratiques dans l'Occident médiéval (IX $-X I I^{e}$ siècle), red. M. Lauwers, Antibes 2002, s. 317-348.

61 „Postea uero obuiauerunt sibi Nogui et episcopus cum optimatibus suis in Guentonia urbe et ex consilio omnium doctorum utrisque partis dati sunt illi VI uiri crudeles in manu episcopi. Adducti sunt ad monasterium sancti Teliaui illis facientibus sex menses in ferreis carceribus. Nogui iterum postulauit ut adducerentur uiri illi ad supradictum monasterium in quo occiderant diaconem et illic diuinum iudicium acciperent. Sinodo quoque iudicante diffinitum est ut unusquisque eorum suum agrum suamque totam substantiam in super et pretium enime suę hoc septem libras argenti redderet ecclesię quam maculauerat", The Text of the Book of Llan Dâv, red. J. G. Evans, J. Rhys, Oxford 1893, s. 220. 
Biorąc pod uwagę powyższe analogie, wolno sobie wyobrazić, iż książę Bolesław, niczym władcy wschodniofrankijscy albo król Nogui, również decydował o losie morderców po konsultacjach z hierarchami, nawet na spotkaniu o charakterze synodu. Dostępne przekazy źródłowe nie potwierdzają jednak takich okoliczności ${ }^{62}$. Piotr Damiani wskazywał wyłącznie na osobę władcy jako na tego, który decydował o losie morderców ${ }^{63}$. Podobnie w dziele Brunona - tym, do którego apelowali święci o uwolnienie skazańców i oddanie ich do klasztoru, był panujący. Można więc powątpiewać, czy w decyzjach księcia duchowni mieli istotny udział, a tym samym, czy za jego decyzjami stały konkretne normy penitencjarne. Wątpliwość ta nie wydaje się jednak szczególnie poważna. Akceptacja poglądów na temat przepojenia rządów Mieszkowica teoriami związanymi z wyrafinowaną ideologią monarszą ${ }^{64}$ pozwala zakładać, że władca sądzić mógł, iż jako zwierzchnik Kościoła zalicza się do grona kapłanów (rex et sacedos), a tym samym uprawniony jest do tego, by osobiście skazywać morderców na ekspiacyjną służbę w klasztorze. Za istotną dla takiego wniosku przesłankę uchodzić może passus Kroniki Thietmara, według którego, gdy książę Bolesław popełnił jakiś grzech, kazał sobie czytać zarządzenia penitencjałów, a następnie pokutował w zgodzie z ich literą ${ }^{65}$ W opinii Andrzeja Pleszczyńskiego przekaz ten

${ }^{62}$ Obradowanie Chrobrego na synodach wraz z biskupami jest bardzo prawdopodobne. Najwcześniejsze przekazy rodzime poświadczające taką praktykę są jednak znacznie późniejsze. Por. P. Krafl, Tzv. sjezdy biskupů v Polsku vrcholného středověku, w: Církev a stát, red. M. Lamparter, Brno 1999, s. 19-30.

${ }^{63}$ Zob. wyżej przyp. 5.

${ }^{64}$ A. Pleszczyński, Gorliwość neofitów. Religijność osobista Przemyślidów i Piastów w X i na początku XI wieku, w: Przemyślidzi i Piastowie - twórcy i gospodarze średniowiecznych monarchii, red. J. Dobosz, Poznań 2006, s. 93-99; idem, Królewskie gesty słowiańskich dynastów w XI wieku na przykładzie Piastów i Przemyślidów, w: „Persona, gestus habitusque insignium". Zachowania i atrybuty jako wyznaczniki tożsamości społecznej w średniowieczu, red. J. Banaszkiewicz, J. Maciejewski, J. Sobiesiak, Lublin 2009, s. 35-46; Z. Dalewski, The Public Dimension of Religion in the Piast Monarchy during the Christianisation Period, APH 2010, 101, s. 37-49; idem, Dlaczego Bolesław Chrobry chciał koronować się na króla?, w: Gnieźnieńskie koronacje królewskie i ich środkowoeuropejskie konteksty, red. J. Dobosz, M. Matla, L. Wetesko, Gniezno 2011, s. 21-42. Dla charakteru władzy Chrobrego istotne są analogie niemieckie. Por. m.in. S. Weinfurter, Idee und Funktion des „Sakralkönigtums” bei den ottonischen und salischen Herrschern, w: Legitimation und Funktion des Herrschers, red. R. Gundlach, H. Weber, Stuttgart 1992, s. 99-127; idem, Sakralkönigtum und Herrschaftsbegründung um die Jahrtausendwende. Die Kaiser Otto III. und Heinrich II. in ihren Bildern, w: Bilder erzählen Geschichte, red. H. Altrichter, Freiburg 1995, s. 47-104; L. Körntgen, Königsherrschaft und Gottes Gnade: zu Kontext und Funktion sakraler Vorstellungen in Historiographie und Bildzeugnissen der ottonisch-frühsalischen Zeit, Berlin 2001; I. Giovanni, Das Sakralkönigtum in Quellen aus ottonischer Zeit: unmittelbarer Bezug zu Gott oder Vermittlung durch die Bischöfe?, „Frühmittelalterliche Studien” 44, 2010, s. 137-152.

${ }^{65}$ Die Chronik des Bischofs Thietmar, lib. IV, c. 92, s. 348. 
traktować należy jako świadectwo autonomiczności Piasta w interesującym nas aspekcie, a jednocześnie jako dowód przywiązania władcy do zwyczajów panowania według modelu królewskiego kapłaństwa. Badacz słusznie zauważył, „że Bolesław Chrobry słuchał kanonów i sam decydował, czy i jakie grzechy popełnił. Żaden kapłan nie występował ponad władcą. Sam panujący również, zgodnie z zapisami kanonów, wyznaczał sobie pokutę. Duchowni asystowali jedynie i pomagali księciu w prowadzonej przez niego akcji" ${ }^{\prime 6}$. Na tej podstawie bez większego ryzyka założyć wolno, iż książę o tego typu samoświadomości gotów był samemu tj. z pominięciem opinii wyższego kleru - decydować o kształcie penitencji morderców eremitów, a tym samym skazywać ich na pobyt w klasztorze, który przecież niewiele wcześniej ufundował. Nie oznacza to jednak, iż decyzji tej nie poprzedziła analiza źródeł prawnych, takich jak penitencjały, zbiory kanonów czy kapitularze.

Przywołane przepisy prawne nie precyzują, na czym dokładnie miała polegać pokutna służba w klasztorach i jaki status, oprócz oczywistego statusu penitenta, zyskiwały osoby przeznaczone do posługi w klasztorze. Dość szczęśliwie przekaz Brunona niesie ze sobą pewien potencjał poznawczy w tym zakresie. Ze źródła wynika mianowicie, iż sens służby morderców miał się sprowadzać do wykonywaniu prac fizycznych na rzecz wspólnoty i opactwa. Wydaje się więc, iż w praktyce

${ }^{66}$ A. Pleszczyński, Świętość i polityka. Henryk II na synodzie w Dortmundzie (rok 1005), w: Świat średniowiecza. Studia ofiarowane Profesorowi Henrykowi Samsonowiczowi, red. A. Bartoszewicz et al., Warszawa 2010, s. 473. Badacz być może słusznie zauważył, że w przekazie Thietmara można się doszukiwać echa publicznej akcji pokutnej. A. Pleszczyński wyszedł jednak z trudnego do udowodnienia założenia, iż akcja ta została podjęta z chęci ideologicznej rywalizacji z Henrykiem II. Bardziej prawdopodobne jest, że tego rodzaju przedsięwzięcie było naśladownictwem pewnej mody. Autorem takich aktów mógł być istotnie Otto III, wyczulony na punkcie ekspiacji win. Por. S. Hamilton, Otto III's Penance: A Case Study of Unity and Diversity in the Eleventh-Century Church, w: Unity and Diversity in the Church, red. R. Swanson, Oxford 1996, s. 83-94; G. Althoff, Otto III, Pennsylvania 2003 (oryg. niem. 1996), s. 132-140. Z władców Niemiec na szerszą skalę spektakle pokutne praktykował jednak dopiero Henryk III, o czym A. A. Larson, Bestowing Pardon and Favor: Emperor Henry III's Pardons in Context, „Viator” 40, 2009, 1, s. 41-69. Równie prawdopodobna, jeśli nie bardziej, jest hipoteza, iż domniemaną akcję pokutną zdeterminowały czynniki wewnętrzne. Ostatnio zauważono, iż tego typu spektakle w obliczu kryzysu organizował współczesny Bolesławowi Æthelred II († 1016). Zob. C. Cubitt, The Politics of Remorse: Penance and Royal Piety in the Reign of Æthelred the Unready, „Historical Research” 5, 2011, 228, s. 179-192; eadem, Individual and Collective Sinning in Tenth- and Eleventh-Century England: Penance, Piety and the Law, $\mathrm{w}$ : Religion and Politics in the Middle Ages. Germany and England by Comparison, red. L. Körntgen, D. Waßenhoven, Berlin-Boston 2013, s. 51-70, oraz L. Roach, Public Rites and Public Wrongs: Ritual Aspects of Diplomas in Tenth- and Eleventh-Century England, ,Early Medieval Europe" 19, 2011, 2, s. 182-203; idem, Penitential Discourse in the Diplomas of King Æthelred the Unready, ,Journal of Ecclesiastical History” 64, 2013, 2, s. 258-276. 
wymiar służby nie był regulowany przez przepisy prawne, lecz posługa penitentów zależała głównie od bieżących okoliczności. Zakładać więc wolno, iż głos decydujący w tych sprawach posiadali mnisi rozeznani w aktualnych potrzebach konwentu. To bracia wyznaczali mordercom harmonogram dnia i wskazywali najpilniejsze prace do wykonania (necessaria seruire). Podejrzewać nawet wolno, że pod względem swego statusu i roli zesłańcy przypominać mogli konwersów. Co ciekawe, źródła klasztorne z tego wczesnego etapu znają ich pod nazwą famuli servientes lub servi/servitores, a to dlatego, że do ich zadań należało usługiwanie zakonnikom, czyli pełnienie służby (servitium). Według najstarszych „Zwyczajów” Cluny w czasach opata Odilona servientes wykonywali różne funkcje, które nie licowały ze statusem brata zakonnego, np. obowiązki odźwiernego ${ }^{67}$. Warto też zauważyć, iż świecką służbę posiadały domy kamedulskie, i to już we wczesnej fazie istnienia. Z Żywota św. Romualda dowiadujemy się na przykład, iż famuli monachorum pełniący funkcję pastuchów żyli niemal jak cenobici - kiedy trzeba było, pościli, nie nadużywali mowy, a nawet karcili się nawzajem rózgami za różnego rodzaju przewiny ${ }^{68}$. Możliwe więc, iż również dla morderców Pięciu Braci zaplanowano zbliżony model funkcjonowania w strukturach klasztoru. Tym bardziej jest to prawdopodobne, iż z Vitae Quinquae Fratrum zdaje się wynikać, że już w eremie mnisi korzystali z pomocy świeckich służących ${ }^{69}$. Należy tu też wspomnieć, iż funkcję sługi pełnić miał przywódca grupy zabójców, zanim dopuścił się zbrodni (,in eorum seruicio ministrare iussus fuit"), a także kucharz Krystyn, o którym Bruno zapisał, jakoby zgodnie z wolą mnichów, „necessitati gratenter seruire solebat"70.

Na poparcie powyższej hipotezy przytoczyć można nawet pewne świadectwo środkowoeuropejskie, a konkretnie fragment tzw. Legendy Większej św. Gerarda, ważnego źródła do wczesnych dziejów Węgier ${ }^{71}$.

${ }^{67}$ Consuetudines Farfenses, w: Consuetudines monasticae, vol. 1, wyd. B. Albers, Stuttgart-Vienna 1900, s. 176; G. Constable, Famuli and conversi at Cluny, „Revue bénédictine" 83, 1973, s. 326-350; M. Didier, Paix et communautés autour de l'abbaye de Cluny, Lyon 2001, s. 271, $301 \mathrm{nn}$. i passim.

${ }^{68}$ VBR, c. 64, s. 105.

${ }^{69}$ M. Derwich, Najstarsze klasztory na ziemiach polskich (do końca XII wieku), w: Kościół w monarchiach Przemyślidów i Piastów, red. J. Dobosz, Poznań 2009, s. 223.

${ }^{70}$ VQF, c. 13, s. 62, 66. Według Kwerfurtczyka Krystyn był sługą (minister), por. s. 68.

${ }^{71}$ BHL 3426. Tytułowy Gerard († 1046) był uczonym benedyktynem weneckiego pochodzenia, który prowadził pracę misyjną w Transylwanii, przez pewien czas mieszkał w pustelni, a także pełnił na dworze Stefana I funkcję nauczyciela królewskiego syna. O nim ostatnio Ș. Turcuș, Saint Gerard of Cenad. The Destiny of a Venetian Around the Year One Thousand, Cluj-Napoca 2006. W zamian za swe zasługi Gerard zostal w 1030 r. mianowany biskupem nowoufundowanej diecezji w miejscowości Morosvár 
Do treści tego przekazu włączono pewną anegdotę, opowiadającą o tym, jak do klasztoru Marii Panny w Csanád schronił się złodziej ${ }^{72}$. Według tego przekazu zdołał on uniknąć śmierci, mimo że został pochwycony przez komesa Csanáda i skazany na śmierć przez powieszenie. Gdy był prowadzony na szubienicę, udało mu się jednak szczęśliwie zbiec. Licząc na zachowanie życia, skazaniec skierował się wprost do pobliskiego klasztoru. Wybór kryjówki okazał się z pozoru trafny, gdyż podążający za nim urzędnicy ścigali go tylko do klasztornej furty, której progów nie przekroczyli z obawy przed złamaniem prawa azylu ${ }^{73}$. Kolejne informacje o losie rabusia przekazał au-

(Morisena) przemianowanej wkrótce na Csanád (Chanadinus, dziś Cenad w Rumunii) na część jej zdobywcy - królewskiego komesa i krewnego o tym imieniu. Diecezja ta była ostatnim biskupstwem fundowanym przez Stefana I. Zob. V. Múcska, o prvých uhorských biskupstvách, „Historický Časopis” 51, 2003, s. 18. Szerzej M. Sághy, L'organisation des Églises en Hongrie autour de l'An Mil: le cas de l'évêché de Csanàd, w: Gerberto d'Aurillac da abate di Bobbio a papa dell'anno 1000, red. F. G. Nuvolone, Bobbio 2001, s. 475 nn.

${ }^{72}$ Chociaż relacja ta skompilowana została raczej dopiero na początku XIV w.,jej treść rzeczywiście wydaje się mieć źródło w czasach św. Gerarda. Za jej wiarygodnością przemawia kilka argumentów. Ma ona charakter ekskursywny i nie łączy się ściśle z głównym wątkiem narracji, co sprawia wrażenie, iż informacja została zaczerpnięta z jakichś zapisków traktujących o dziejach klasztoru i katedry, najpewniej z zaginionego żywota biskupa spisanego w związku z próbą wyniesienia hierarchy na ołtarze zakończoną sukcesem w 1083 r., względnie z legend związanych z rodem Sunad. Z punktu widzenia docelowego odbiorcy nie przedstawiała ona żadnej wartości. Nie służyła uświęceniu osoby głównego bohatera Żywota, nie ma też charakteru toposu hagiograficznego, a poza tym opisuje sankcję właściwą dla okresu wczesnego średniowiecza, którą zarzucono wraz z „racjonalizacją” prawa kościelnego w XII w. (przynajmniej jeśli chodzi o świeckich winowajców). Włączenie owego wątku do opowieści o świętym biskupie nie miało także najmniejszego znaczenia z perspektywy jej autora. Te argumenty, jak również to, iż w treści anegdoty pojawia się osoba Csanáda, postaci z otoczenia króla, faktycznego wspomożyciela Gerarda, zdaje się przemawiać za jedenastowieczną genezą wątku. Na temat wartości historycznej Żywota zdania są podzielone. Zob. C. A. Macartney, The Lives of St Gerard, w: idem, Studies on Early Hungarian and Pontic History, red. L. Czigány, L. Péter, London 1999, s. 65-99; idem, The Medieval Hungarian Historians, Cambridge 1953, s. 154-161; J. Horváth, Die Entstehungszeit der grossen Legende des Bischofs Gerhard, „Acta antiqua Academiae Scientiarum Hungaricae” 8, 1960, s. 185-219; idem, La Légende majeure de l'évêque Gérard et les débuts de notre historiographie médiévale, „Annales Universitatis Scientiarum Budapestiensis. Sectio philologica" 1961, s. 3-20. Ostatnio także L. Veszprémy, Royal Saints in Hungarian Chronicles, Legends and Liturgy, w: The Making of Christian Myths in the Periphery of Latin Christendom (c. 1000-1300), red. L. B. Mortensen, Copenhagen 2006, s. 222-223, który wskazał na znaczną liczbę wiarygodnych wątków. Legenda maior uważana jest za wartościowe źródło dla problemu chrystianizacji Węgier przez Annę Kuznetsovą (eadem, Signs of Conversion in vitae sanctorum, w: Christianizing Peoples and Converting Individuals, red. G. Armstrong, I.N. Wood, Turnhout 2000, s. 125-132) oraz Marianne Sághy (eadem, op. cit., s. 475-476).

${ }^{73}$ Prawo azylu kościelnego było jednym z pierwszych, jakie zaszczepiano na terenach chrystianizowanych. Zob. D. Fruscione, Das Asyl bei den germanischen Stämmen im frühen Mittelalter, Köln 2003. Tak też działo się najpewniej w Europie Środkowej, za 
tor w formie bardzo skróconej. Według słów relacji urzędnicy powinszowali uciekinierowi zwinności i sprytu, jednak wkrótce okazało się, że sytuacja zbiega wcale nie była do pozazdroszczenia. $Z$ kolejnego zdania wynika bowiem, iż złodziej został przekazany na własność klasztorowi - jak dodał autor - „pro pulsatore cunctis diebus vite sue"74. Termin pulsator nie został tu rzecz jasna użyty w swym podstawowym znaczeniu, lecz jak można się domyślić, oznacza po prostu dzwonnika (pulsator campanarum).

Informacja o funkcji, jaką dożywotnio przydzielono złodziejowi, pozwala sądzić, iż człowiek ten podarowany został (datus est) konwentowi właśnie jako servitor, który podobnie jak bracia świeccy pracujący na rzecz klasztorów benedyktyńskich w Europie Zachodniej miał wykonywać pracę fizyczną po to, ażeby mnisi nie byli odciągani od ich głównego zadania, czyli modlitwy. Przykład węgierski pokazuje jednak, jak istotną rolę w tego rodzaju sytuacjach odgrywały czynniki wynikające z okoliczności bieżących. Zbieg został przekazany opactwu przede wszystkim dlatego, że znalazł się w jego murach, uciekając przed wymiarem sprawiedliwości. Najpewniej żadne rozwiązania prawne nie były w tym przypadku brane pod uwagę. Można za to się domyślać, iż komes Csanád (raczej bez konsultacji $\mathrm{z}$ władcą, choć nie jest to wykluczone) wszedł w kontakt z przełożonymi zgromadzenia - zapewne samym Gerardem i obaj ustalili, że takie rozwiązanie będzie w danej sytuacji najlepsze. W ten sposób instytucja kościelna zyskała sługę, uratowana została dusza złodzieja przed zatraceniem, a on sam przykładnie ukarany. Nie wykluczone, iż przekaz Legendy stanowi ślad szerszej praktyki wspierania młodych konwentów benedyktyńskich przez odstępowanie mnichom skazańców, która jednak pozostawać musiała tylko luźno związana z tradycją pokutną ${ }^{75}$.Jeśli przyjmiemy, iż takie zjawisko

czym przemawiać może najstarszy zwód prawny Słowian z okresu misji cyrylometodiańskiej: Zakon sudnyj ljudem, wyd. H.W. Dewey, A. M. Kleimola, Ann Arbor 1977, c. 16, s. 37. Prawo azylu niewatpliwie znane było na Wegrzech za panowania Stefana I. Zob. Decreta S. Stephani regis, lib. II, c. 19, s. 11; D. Hrnčiarová, Počiatky a vývoj azylového práva $v$ stredoveku s osobitým dôrazom na Uhorsku, ,Studia archaeologica slovaca mediaevalia” 3/4, 2000-2001, s. 243-248.

${ }^{74}$ „Accidit autem eo tempore, quod Chanadinus comes haberet quendam vinctum, qui pro reatu suo ad patibulum duceretur. Qui evadens manus eorum, qui ipsum vinctum ducebant, in monasterium Beate Virginis insiliens evasit. Qui eum veliciter subsequentes, usque ad ostium monasterii venerunt. Dicebantque ei: «Bene tibi vulpecula, que laqueum perditionis evasisti et cum pelle, qua spoliaberis, in foveam introisti». Ex quo factus est risus magnus in populo. Idem vero vinctus datus est monasterio pro pulsatore cunctis diebus vite sue", Legenda sancti Gerhardi episcopi, wyd. E. Madzsar, w: Scriptores rerum Hungaricarum, vol. 2, red. E. Szentpétery, Budapest 1938, c. 12, s. 449.

${ }^{75}$ Trisha Olson pokazała jednak, że praktyka azylu obligowała duchownych do interweniowania na rzecz zbiegów poprzez szukanie rozwiązań kompromisowych. Nakładanie pokuty na azylantów sprawiało, iż wina sprawcy nie pozostawała bez kary, 
istniało na Węgrzech w XI w., należy raczej uznać je za przejaw polityki wspierania organizacji kościelnej przez monarchę i podległy mu aparat władzy ${ }^{76}$.

Powyższy przykład skłania także do zastanowienia się nad okolicznościami bieżącymi, które wpłynęły na decyzję o umieszczeniu morderców Pięciu Braci w klasztorze. Niestety problem ten w znacznym stopniu wymyka się jednak historycznemu poznaniu, głównie z powodu niejednoznaczności słów Brunona. Otóż fragment Żywota zawierający pouczenie męczenników skierowane do księcia zdaje się przemawiać za tym, iż stroną, której zależało na pozyskaniu skazańców, byli przede wszystkim mnisi:

Już dosyć - mówili - ukazywaliśmy się nawet świeckim ludziom, czyniąc liczne znaki i cuda. [- - ]; jeśli nie uszanowanie dla Boga, to jednak niezwykłość sprawy już przy pierwszych cudownych znakach powinna by była wpłynąć na uwolnienie tych, których [książę] trzyma w strasznym więzieniu, [- - ] choć [oni] w niedobrym zamiarze przez zabójstwo zgotowali nam to szczęście. [Powinna też wpłynąć] i na powzięcie postanowienia, aby im nie szkodzić, żon i dzieci wraz z ich mieniem nie skazywać na ruinę, lecz przeznaczyć ich do wiecznej służby dla Boga w świętym miejscu, by mogli [w nim] pokutować i osiągnąć życie [wieczne]. My na twoją chwałę dobrowolnie przyszliśmy tu i w twoim kraju znaleźliśmy przeobfite miłosierdzie łaskawego Zbawiciela. Z całą także pokorą dostarczyłeś nam, gdyśmy przebywali w ciele, potrzebnych rzeczy. Dokończ dobrego dzieła, które rozpocząłeś! Uczyń, cośmy powiedzieli dla uwolnienia uwięzionych i zlitowania się nad naszymi zabójca$\mathrm{mi} !^{77}$.

a pretensje wrogów lub ścigających sprawcę urzędników były częściowo zaspokojone. Zob. T. Olson, Sanctuary and Penitential Rebirth in the Central Middle Ages, w: Boundaries of the Law. Geography, Gender and Jurisdiction in Medieval and Early Modern Europe, red. A.J. Musson, Aldershot 2005, s. 38-52.

76 O prokościelnej polityce pierwszych chrześcijańskich władców Węgier G. Kiss, Állam és egyház a 11-12. századi törvényalkotásban, w: A magyar államiság első ezer éve, red. M. Font, I. Kajtár, Pécs 2000, s. 67-101; V. Múcska, K otázke vztahu uhorského krála k cirkvi $v$ 11. storočí, „Studia Historica Tyrnaviensia” 3, 2003, s. 335-344; L. Koszta, State Power and Ecclesiastical System in Eleventh Century Hungary, w: "In my spirit and thought I remained a European of Hungarian origin". Medieval Historical Studies in Memory of Zoltán J. Kosztolnyik, red. I. Petrovics, S.L. Tóth, E. A. Congdon, Budapest 2010, s. 67-78.

77 ŻPB, s. 104 (z własnymi korektami); „Iam, inquiunt, satis apparuimus etiam et sęcularibus uiris in multis signis et portentis; quare non creditis nobis? Homines nunc ferreo, nunc ligneo, nunc rupto, nunc sano uinculo per Dei potentiam et misericordiam liberauimus, et si non reuerentia Dei, tamen causa nouitatis liberos dimittere in primitius signis oporteret, quos ille in dira custodia tenet. Similiter uiros, qui quamuis non bono animo occisis nobis hec bona dedere, illis non nocere, uxores et filios cum substancia eorum non disperdere, sed ut possint habere penitentiam et uitam conuertere eos in ęternum Dei seruicium ad sanctum locum oporteret. Nos in tuam gloriam 
Te słowa zdają się wskazywać, iż Bruno oddawał za ich pośrednictwem poglądy członków młodego zgromadzenia, którzy próbowali wyprosić łaskę dla skazańców i podarowanie ich na rzecz klasztoru. W pewnej sprzeczności z tą hipotezą stoi jednak następna wiadomość odnotowana przez Kwerfurtczyka. Otóż opat klasztoru miał się sprzeciwić powiadamianiu księcia „o tych sprawach”, a to dlatego, by Bolesław „nie sądził, że mówi żartem, wiedział bowiem już o nim, iż nie bardzo dowierza"78. Na podstawie tych sprzecznych i nie do końca jasnych stwierdzeń powziąć można uzasadniony domysł, iż Bruno wolał zataić przed czytelnikiem niektóre z czynników, jakie doprowadziły do zesłania morderców w mury klasztoru. Jego głównym celem było przedstawienie świętych w roli patronów młodego zgromadzenia, którzy nie tylko czuwają nad jego losem ${ }^{79}$, ale też decydują w istotnych sprawach dotyczących zabójców i zarazem ekonomiki zgromadzenia $^{80}$. Poza tym Bruno powziął wyraźny zamiar przedstawienia męczenników, zwłaszcza Benedykta i Jana, jako kierujących się głębokim poczuciem miłosierdzia, a jednocześnie ukazania ich w roli naśladowców Chrystusa, który również wybaczył swym oprawcom. Kierując się takimi dążeniami, musiał Bruno ukazać Chrobrego, a nawet opata klasztoru, w pewnej kontrze do świętych. Nie będzie więc pozbawione podstaw stwierdzenie, że za takim ujęciem kwestii kryje się konfabulacja autora, mająca marginalizować rolę księcia w całym przedsięwzięciu.

Wobec tych trudności nie sposób rzetelnie odpowiedzieć na postawione pytanie o bieżące okoliczności towarzyszące umieszczeniu zabójców

uoluntate huc uenimus et in tua terra superhabundantem misericordiam benigni Saluatoris inuenimus; omni etiam humilitate necessaria nostra nobis in carne ambulantibus ministrasti; comple bonum quod cepisti, in finem, fac quod diximus in libertate catenatorum et in misericordia nostrorum homicidarum", VQF, c. 25, s. 75-76.

${ }^{78}$ ŻPB, s. 105; „Ne putaret se causa dicere ludicri, quem minus iam credere uidit, talia seniori innotescere abbas non permisit", VQF, c. 25, s. 76.

${ }^{79}$ W XI w. upatrywanie w świętych patronach zarządców klasztorów stojących ponad opatami było na gruncie hagiografii zjawiskiem dość powszechnym. Dobrym tego przykładem bogate piśmiennictwo Fleury: A. Davril, Un monastère et son patron. Saint Benoit, patron et protecteur de l'abbaye de Fleury, „Cahiers de recherches médiévales et humanistes" 8, 2001, s. 43-55.

${ }^{80} \mathrm{Z}$ opublikowanych niedawno badań nad hagiografią Saint-Benoît-sur-Loire wynika, że mnisi postrzegać mogli klasztorną siłę roboczą (famuli, servi) jako grupę bezpośrednio podporządkowaną świętemu patronowi, który na wzór pana feudalnego chronił jej przedstawicieli w chwilach zagrożenia, jednak w zamian wymagał posłuszeństwa. Zob. C. Dejardin-Bazaille, La relation de dépendance entre saint Benoît et ses serfs: contrainte ou protection?, „Le Moyen Age” 113, 2007, 2, s. 383-292. Wydaje się, iż z podobną sytuacją mamy do czynienia w opisie Brunona z Kwerfurtu - tu święci w zamian za uratowanie życia oczekiwali pokornej służby na rzecz zgromadzenia. W tym kontekście warto także przypomnieć, że przywódca morderców już wcześniej pełnił funkcję sługi eremitów, zaliczał się więc do familii. 
w klasztorze. Domyślać wolno się jedynie, iż wydanie decyzji o zesłaniu morderców do pracy w opactwie poprzedziły negocjacje między księciem a mnichami. Jest całkiem możliwe, że inicjatywa takiego rozwiązania wyszła ze strony zakonników, nie ulega jednak wątpliwości, iż rozstrzygnięcie należało do panującego, który kierował się wieloma względami ${ }^{81}$. Pośród nich na czoło wysuwały się omówione czynniki zwyczajowo-prawne i religijne. Tak odrażająca i świętokradcza zbrodnia wymagała od chrześcijańskiego władcy reakcji zgodnej z wymogami świętych kanonów i kapitularzy. Domyślać można się jednak także ekonomicznych konotacji książęcej decyzji. Tradycja skazywania na służbę do klasztoru uwzględniała przecież na pierwszym miejscu konieczność zadośćuczynienia przez odpracowanie winy, co prowadzić miało do - niekiedy choćby tymczasowego - wzmocnienia potencjału gospodarczego skrzywdzonego kościoła. Taki wniosek zdaje się wynikać z lektury „Prawa Bawarów” (ok. 744-748), w którym znalazł się przepis regulujący kwestię zabójstwa biskupa. Według tenoru tejże ustawy sprawca zbrodni zobligowany był do zadośćuczynienia świątyni katedralnej. Jeśli jednak nie posiadał wystarczającej ilości złota, powinien przekazać cały swój dobytek, a także wraz z żoną i dziećmi oddać się „ad ecclesiam in servitium” i w ten sposób spłacić swój dług ${ }^{82}$. Kiedy ktoś oddawał się do klasztoru na pokutną służbę w wyniku morderstwa na duchownym, ofiarował jednocześnie instytucji kościelnej cały swój majątek ${ }^{83}$. Przypomnijmy, że w wyżej opisanej sprawie zabój-

${ }^{81}$ Należy niniejszym zauważyć, że w tradycji kościelno-prawnej istniała zawsze wyraźna tendencja odmawiania mnichom prawa udzielania pokuty bez zgody kapłana. Zob. Theodorus, Poenitentialae, wyd. F. W.H. Wasserschleben, Die Bußordnungen, s. 209.

82 „Et si aurum non habet, donet aliam pecuniam mancipia terram villas vel quicquid habet, usque dum impleat debitum. Et si non habet tantum pecuniam, se ipsum et uxorem et filios tradat ad ecclesiam illam in servitium, usque dum se redimere possit", Lex Baiwariorum, wyd. E. Schwind, Hannoverae 1926, MGH Leges nationum Germanicarum, t. 5, cz. 2, c. 10, s. 282. Zwód powstał za sprawą króla Odilona przy udziale episkopatu. Por. J. Couser, „Let Them Make Him Duke to Rule that People”: The Law of the Bavarians and Regime Change in Early Medieval Europe, „Law \& History Review” 30, 2012, 3, s. 865-899. Cytowany przepis proweniencji bawarskiej stał się podstawą normy cesarskiej Ludwika Pobożnego. W kapitularzu tego władcy z 819 r. zapisano, iż każdy, kto skrzywdził duchownego, a nie posiada wystarczających środków, by wypłacić odszkodowanie, powinien oddać się „in servitium” na rzecz kościoła. Nie ma tu jednak mowy o przekazaniu majątku ani rodziny. Zob. „Et qui non habet unde ad ecclesiam persolvat, tradat se in servitium eidem ecclesiae, usque dum totum debitum persolvat", Capitula legibus addenda, wyd. A. Boretius, MGH Capitularia regum Francorum, c. 2, s. 281.

${ }^{83}$ Źródła potwierdzające tego typu praktykę stanowią niestety wielką rzadkość. Dla wieku XI zob. dokument wystawiony przez mordercę biskupa Astorgi - oddawał się on wraz z majątkiem na wysługę do klasztoru San Pedro de Montes, który zresztą obrabował i sprofanował: „Ego Pelagio, mea culpa, recognosco me in scelera mea, 
stwa gwentyjskiego diakona król Nogui wraz z biskupem Padarnem orzekli na synodzie, iż sprawcy - oprócz tego, że należy ich samych przekazać kościołowi, w którym służyła ich ofiara - powinni dać owej placówce wszystko, co posiadają: „ut unusquisque eorum suum agrum suamque totam substantiam [- ] redderet ecclesię quam maculauerat" ${ }^{84}$. Również wszystkie dobra Arduina z Ivrei oraz jego ludzi przypaść miały kościołowi, który tak dotkliwie skrzywdził ${ }^{85}$. Bardzo więc możliwe, że podobną sytuację przewidywała decyzja księcia Bolesława, a skoro służba morderców trwać miała dożywotnio, jej celem było wzmocnienie gospodarcze placówki, za której prężność książę jako jej fundator i patron czuł się bez wątpienia odpowiedzialny. Pewność w tej materii dać może jednak tylko prawidłowe odczytanie kluczowego fragmentu Żywota Pięciu Braci, relacjonującego żądanie wyjawione bratu Andrzejowi. Na jego podstawie trudno orzec niestety, czy ruina dobytku skazańców oraz nędza żon, dzieci brać się miały wyłącznie z rozłąki spowodowanej śmiercią morderców w książęcym karcerze lub ich wieloletniego uwięzienia. Sądzić jednak raczej wolno, że decyzja Bolesława Chrobrego uwzględniała chrześcijański postulat nierozłączania rodzin i ślubów małżeńskich, a jeśli tak, oznaczałoby to, iż prawdopodobnie książę przydzielił klasztorowi „ad servitium” zabójców wraz z ich żonami, dziećmi i całym ich dobytkiem ${ }^{86}$.

Podsumowując niniejsze rozważania, stwierdzić należy, że chociaż nasza wiedza na temat tego, co stało się z mordercami Pięciu Braci eremitów nie jest pełna ani wolna od niejasności, w wiadomościach Brunona o umieszczeniu zabójców w klasztorze dostrzegać należy refleks świadomej i w pełni przemyślanej decyzji polskiego władcy. Bolesław Chrobry jako władca chrześcijański, na którego barkach spoczywała dbałość o religijną i moralną czystość swego ludu, czuł się zobowiązany do wyeliminowania z grona podległej sobie wspólnoty sprawców tak strasznej zbrodni - brutalnego mordu na eremitach, sługach Bożych, a zarazem profanacji miejsca świętego. Jak się okazuje, uczynił to w sposób

quod feci contra Deum [- - ]. Id est: Monasterios devastavi, rebus sanctae ecclesiae contempni, et insuper magnum magna cogitavi ut dominum meum atque pentificem morti traderem. Propterea me recognosco culpabilem contra Deum et sanctis suis et vobis patre nostro domino Petro, episcopo. Et propterea trado corpus meum et portionem meam ad istum locum venerabilem sancti Petri apostoli, ut fiat mihi testes vel diem judicii cum omnibus sanctis ante dominum nostrum Jesu Christum", Tumbo viejo de San Pedro de Montes, wyd. A. Quintana Prieto, Léon 1971, nr 27, s. 113.

${ }^{84}$ Zob. wyżej przyp. 61.

${ }^{85}$ Die Urkunden Otto des III., wyd. T. Sickel, Hannover 1893, MGH Diplomatum regum et imperatorum Germaniae, t. 2, cz. 2, nr 323, s. 749-751.

${ }^{86}$ Jeszcze trudniej stwierdzić, czy miała być to służba dziedziczna. Taki wniosek, jednak bez uzasadnienia, postawił S. Arnold. Zob. Pierwsza konferencja, s. 172. 
zgodny z najlepszymi postulatami kanonicznymi swoich czasów i w duchu prawdziwie monarszym. Nie skazał ich na śmierć, nie pozwolił umrzeć sprawcom w więzieniu, lecz w zgodzie z zaleceniami kanonów polecił umieścić ich w klasztorze, aby tam podjęli dożywotni trud pokuty. W ten sposób zyskiwał pewność, że ich ekspiacja poprowadzona zostanie w sposób należyty i skuteczny pod nadzorem mnichów, a złoczyńcy trudem swej pracy na rzecz Boga i zgromadzenia zadośćuczynią za zbrodnię, której się dopuścili. Poza tym domyślać się wolno, iż zesłanie morderców do klasztoru było powodowane koniecznością zrekompensowania świętym szkody, jakiej doznali, a zarazem troski Chrobrego o gospodarczą prężność opactwa. Takie odczytanie Brunonowego świadectwa pozwala spojrzeć po raz kolejny na postać Bolesława Chrobrego jako na władcę ambitnie zaprowadzającego w swej domenie standardy cywilizacji „starego chrześcijaństwa”. Ukazuje także nowe oblicze panującego, jakże różne od tego, które opisał Thietmar w znanym wątku poświęconym straszliwym karom, jakie Bolesław z gorliwością neofity kazał stosować wobec naruszających zaprowadzany w jego państwie porządek religijny i moralny.

\section{Aeternum Dei servitium ad sanctum locum. The Penance of the Murderers of Five Martyred Brethren in an Account by Bruno of Querfurt}

This article is a first attempt at systematically considering the penance imposed by Bolesław the Brave on the assassins of the so-called Five Martyred Brethren, described in Vita Quinquae Fratrum Eremitarum by St. Bruno of Querfurt (BHL 1147). The killers of the hermits were condemned to life-long penance in an abbey founded by Duke Bolesław on the site of the desecrated hermitage soon after the crime (about 1003-1006). The posed research questions concern, predominantly, the reasons for this particular penance, its purpose and character, as well as sources and cultural context in the form of the tradition of monastic penance (Klosterbuße).

The conducted analysis leads to a conclusion claiming that putting murderers in monastery was the result of a carefully planned decision of the Polish ruler, taking into consideration a number of the factors, including legal requirements. Comparative survey made it possible to find many significant West European analogies to the penance imposed on murderers of Five Martyred Brethern both in normative sources (capitularies, penitentials, canon law collections, synodal statutes) and those referring to the penitentiary practice of the early Middle Ages. Their confrontation with the account by Bruno of Querfurt demonstrates that the solution accepted by Bolesław the Brave took into consideration regulations known from penitential or canonical tradition condemning the killers of clergymen to life-long penance in a monastery known from the seventh century as servitium Dei. Following their contents, the duke resigned from his original intention to incarcerate the felons in ducal prison or to sentence them to death in 
favour of chastisement corresponding to standards that should be respected by a Christian ruler. The penalty did not deprive the perpetrators of the perspective of salvation.

The proposed analysis casts a new light not only on the issue of penitential practice during the Early Piast era but also on the wider problem of the application of regulations borrowed from Western culture in the domain ruled by Bolesław the Brave. The article expands heretofore knowledge about the part performed by Duke Bolesław in binding his state with the circle of post-Carolingian Latin civilisation through a conscious acculturation of Christian customs and norms.

Translated by Aleksandra Rodzińska-Chojnowska 